\title{
Vývoj pojmu osoba v právu a jeho reflexe v ABGB a v občanském zákoníku z roku 2012
}

\author{
Jakub Stromšík
}

\author{
Univerzita Karlova, Právnická fakulta \\ Kontaktni e-mail: jakub@stromsik.cz
}

\begin{abstract}
Development of the Concept of a Person in Law and its Reflection in the Civil Code of Austria (ABGB) and in the Czech Civil Code of 2012
\end{abstract}

\begin{abstract}
:
This study brings a comprehensive historical perspective on the development of the concept of a person in the legal sense in the territory of the Czech lands. This study deals with the philosophical definition of this term and examines the natural law basis of this issue. Emphasis is placed on the comparison of the legal regulation of natural persons in the Civil Code of Austria (ABGB) which was enacted in 1811, and in the Czech Civil Code from 2012. The authors of the Czech Civil Code designate as the ideological source of the recodification the draft of the Czechoslovak Civil Code from 1937, which was de facto modern revision of the $\mathrm{ABGB}$, so it is important to take into account the relevant $\mathrm{ABGB}$ provisions when interpreting the Czech Civil Code. It is also reasonable to consider the historical origins of these provisions, while also examining how their interpretation has evolved over time.
\end{abstract}

\section{Keywords:}

person in the legal sense; natural person; historical development of the term person; Civil Code of Austria (ABGB); Czech Civil Code 2012

\section{Klíčová slova:}

osoba v právním smyslu; fyzická osoba; historický vývoj pojmu osoba; Všeobecný zákoník občanský (ABGB); český občanský zákoník 2012

DOI: 10.14712/2464689X.2020.34

Zdá se, že postavení osob v právním smyslu není pro současné právní teoretiky př́liš atraktivním tématem. Autoři většiny publikací, které se v poslední době alespoň okrajově věnovaly tomuto tématu, zaměřují svou pozornost zejména na teoretické vymezení právnických osob, rozebírají dopady různých teorií definujících právnické osoby, a problema- 
tiku osob fyzických považují za vyřešenou. ${ }^{1}$ Právně-teoretická definice osob (tedy nejen osob právnických) má ale klíčové koncepční dopady na pojetí práva jako celku, nebot' právě postavení osoby v právním smyslu je dominantním prvkem veškeré právní regulace. Přestože je právo multidimenzionálním fenoménem a vícevýznamovým výrazem, ${ }^{2}$ převažující je bezpochyby jeho normativní význam. Právo je vnímáno jako soustava právních norem, kterými se reguluje chování osob, které jsou uznávané nebo stanovené státem, a jejichž dodržování stát mocensky vynucuje.

Cílem této studie je přinést historizující pohled na vývoj pojmu osoba v právním smyslu na území českých zemí. Studie se mimo jiné zabývá tím, jak se v minulosti měnil vztah mezi člověkem a pojmem osoba. Dnešní význam pojmu osoba a jeho odlišení od pojmu člověk je totiž výsledkem dlouhého a komplikovaného historického vývoje. Právo až v relativně pozdní fázi přebíralo výsledky tohoto vývoje, který probíhal v jiných společenských oborech (zejména ve filozofii). Bez tohoto vývoje by právní doktrína nedospěla $\mathrm{k}$ dnešnímu pojetí osoby.

Dalším cílem je porovnat právní úpravu fyzických osob v obecném zákoníku občanském z roku 1811 (ABGB) a českém občanském zákoníku z roku 2012, a to zejména úpravu tzv. pasivního statusu osoby v právním smyslu (tj. právní osobnosti). Aby toto bylo možné, je nezbytně nutné nejdříve zkoumat právně-historický, resp. právně-filozofický základ této úpravy.

Jelikož redaktoři nového občanského zákoníku označují za základní obecný ideový zdroj rekodifikace vládní návrh občanského zákoníku z roku 1937, který byl de facto modernizační revizí rakouského obecného zákoníku občanského, je při interpretaci občanského zákoníku z roku 2012 užitečné přihlížet k relevantním ustanovením ABGB, zohlednit historický původ těchto ustanovení a zároveň zkoumat, jak se jejich výklad vyvíjel v čase. Rakouští civilisté při aplikaci soukromého práva těží ze stability svého kodexu a mohou se zároveň opřít o více než dvousetletý doktrinální vývoj a rozsáhlou judikaturu. ${ }^{3}$ Česká právnická obec tuto výhodu nemá, a tak při aplikaci konkrétních ustanovení občan-

1 V českém prostředí jde např́klad o knihu BERAN, K. Pojem osoby v právu. Praha: Leges, 2012, nebo o publikaci HURDÍK, J. Osoba a její soukromoprávní postavení v ménícím se světě. Brno: Masarykova univerzita, 2004. Ve středoevropském prostoru je pak nutné zmínit díla OSTHEIM, R. Zur Rechtsfähigkeit von Verbänden im österreichischen bürgerlichen Recht. Wien: Springer, 1967, RITTNER, F. Die werdende juristische Person. Tübingen: Mohr Siebeck, 1973, RAISER, T. Der Begriff der juristischen Person Eine Neubesinnung. Archiv für die civilistische Praxis, 1999, 199, s. 104-144, nebo BYDLINSKI, F. Die „Person“ im Recht. In: KALSS, S. - NOWOTNY, Ch. - SHAUER, M. (eds.). Festchrift Peter Doralt zum 65. Geburstag. Wien: Manz, 2004.

2 GERLOCH, A. Teorie práva. 7. vyd. Plzeň: Aleš Čeněk, 2017, s. 21.

3 Např. první Zeillerův komentář k ABGB (ZEILLER, F. von. Commentar über das Allgemeine bürgerliche Gesetzbuch: für die gesammten deutschen Erbländer der österreichischen Monarchie. Wien - Triest: Geistinger, 1811). Další brzy následovaly: komentář Michaela Schustera (SCHUSTER, M. Theoretisch-praktischer Kommentar über das allgemeine bürgerliche Gesetzbuch. Altstadt: Scholl'schen Buchdruckerei, 1818), devítisvazkový komentáŕ Franze Xavera Nippela (NIPPEL, F. X. Erläuterung des allgemeinen bürgerlichen Gesetzbuches. Graz: Damian und Sorge, 1830-1838), trrídílný komentáŕ Moritze von Stubenraucha (STUBENRAUCH, M. von. Das allgemeine burgerliche Gesetzbuch, Wien: Friedrich Manz, 1854-1858). Na tato díla navazují např. autoři nejznámějšího moderního komentáře $\mathrm{k}$ ABGB: KOZIOL, H. - BYDLINSKI, P. - BOLLENBERGER R. Kurzkommentar zum ABGB, Allgemeines bürgerliches Gesetzbuch, EheG, KSchG, IPR-G, Rom I-, Rom II- und Rom III-VO. 4. vyd. Wien: Verlag Österreich, 2014. 
ského zákoníku roste význam historického a komparativního výkladu právních norem. Tuto studii je tedy nutné vnímat jako příspěvek k diskusi probíhající v právnické obci, jejímž cílem je dobrat se skutečného významu jednotlivých ustanovení a institutů občanského zákoníku.

Dalším cílem studie je ověřit hypotézu, že se redaktoři občanského zákoníku z roku 2012 nezaměřili na precizní teoretické vymezení osob v právním smyslu, resp. na odlišení pojmu osoba od pojmu člověk, a nerespektovali tak několik staletí trvající vývoj právní doktríny v této oblasti. Druhou zkoumanou hypotézou je naopak tvrzení, že pojem osoby byl v ABGB vymezen přesněji a v souladu s tehdejšími poznatky právní vědy.

\section{Právní úprava fyzických osob v obecném zákoníku občanském}

Subjekty práv a povinností nazývá občanské právo osobami. Obecný zákoník občanský rozlišuje dvě skupiny subjektů, a to osoby fyzické a osoby právnické (resp. v původním pojetí osoby morální). O každém člověku v $§ 16$ stanoví, že „má vrozená, již rozumem poznatelná práva, a nutno jej tudíž považovati za osobu“ (tedy za osobu ve smyslu právním). Vzhledem k době vzniku zákoník dodal, že „otroctví nebo nevolnictví a k tomu se vztahující výkon moci nejsou v těchto zemích dovolena“. ${ }^{4} \mathrm{O}$ právnických (morálních) osobách, resp. „dovolených tělesech“ se hovoří v § 26 ABGB: „Naproti jiným osobám používají dovolené společnosti zpravidla stejných práv jako jednotlivé osoby.“ Z jiných částí zákoníku lze dovodit, že dalšími právnickými osobami jsou stát, země a obec $(\$ 27$, $1454,1472) .{ }^{5}$ Rakouský občanský zákoník co do úpravy právnických osob vycházel z tehdejší úrovně právní vědy, ústřední byla „,principiální role osob přirozených (fyzických) daná prrirozenoprávním základem celého kodexu a osoby právnické upravil do jisté míry jako výsledek legislativních náhod a systematické nezralosti“. 6

V následujících podkapitolách podrobně rozeberu historický vývoj pojmu osoba od antiky přes vrcholný středověk, kdy došlo k přijetí rakouského občanského zákoníku, po moderní dějiny. Tento výklad je nezbytný pro pochopení základních principů pojetí osob v ABGB.

\subsection{Pojem osoba v antice}

Pojem osoba (řecky prosopon, latinsky persona) se zrodil a oddělil od označení člověka (řecky anthropos, latinsky homo) v antice. Podle některých názorů se tak stalo až s rozšířením křest'anství, ale není tomu tak. ${ }^{7}$ Původním řeckým výrazem k označení člověka byl pojem anthropos. Vedle něj se používaly výrazy soma nebo psyché, které sloužily k označení konkrétní (individuální) charakteristiky člověka. Výraz soma používal řecký básník Hésiodos k označení konkrétního individuálního člověka tvořícího předmět pozoro-

$4 \quad$ K problematice zrušení nevolnictví více v: FRAIS, J. Reformy Marie Terezie a Josefa II. (nejen v českých a moravských zemích). Třebíč: Akcent, 2005; nebo v HAUBELT, J. Zrušení nevolnictví: významná událost $v$ dějinách našeho lidu. Praha: Horizont, 1981.

5 KRČMÁr̆, J. Právo občanské I. Výklady úvodni a část všeobecná. Praha: Wolters Kluwer, 2014, s. 133.

6 LAVICKÝ, P. a kol. Občanský zákoník I. Obecná část (\$ 1-654). Komentář. Praha: C. H. Beck, 2014, s. 147.

7 Tento názor zastával např́iklad Jaromír Sedláček: „Rozlišení je dáno teprve křest’anstvím a teprve v křest’anské éře počíná se užívat slova persona ve smyslu osobnosti, tj. bytost sebevědomá, rozumná, svobodná, stanovící si své cíle. “ SEDLÁČEK, J. Občanské právo československé. V̌seobecné nauky. Praha: Wolters Kluwer ČR, 2012, s. 137-138. 
vání jinou osobou. Pojmu soma a jeho latinského ekvivalentu caput bylo později užíváno „k označení individua jako osoby v právním smyslu“. 8

Namísto dvou výše uvedených pojmů se ale postupně začal prosazovat výraz prosopon. Původně se toto slovo používalo k označení divadelní masky v antických komediích a tragédiích. Podle Aristotela byl původní význam tohoto slova „tvářc“, nebo „obličej“, takže souvislost s divadelní maskou je zřejmá. Vývoj významu slova prosopon však pokračoval, později byl tímto pojmem označován typ člověka, který daná maska představovala. Z typu člověka pak byl již krok k označení divadelní role, a nakonec byl abstrakcí význam tohoto slova přenesen na označení společenské role, resp. poslání daného člověka ve společnosti, což jsou znaky charakterizující jednotlivce. Na konci vývoje tak starořečtina výrazu prosopon přiznávala význam charakterizující jednotlivce vzdáleně podobný dnešnímu pojmu „osoba“. 9

Podobně jako $v$ jiných oborech převzala latina řecké pojmosloví týkající se člověka a osoby i s jeho vývojovými tendencemi. Dominantním výrazem v antickém Rímě se tak pro označení jednotlivce, resp. jeho charakteristik nebo vlastností stal pojem persona, který stejně jako v prrípadě pojmu prosopon dřive označoval masku. ${ }^{10}$ Je příznačné, že stejně jako je v současné době obtížné formulovat vymezení pojmu osoba, tak dodnes nebyl zcela objasněn význam latinského pojmu persona ve všech jeho nuancích. V Rímě dále probíhal vývoj významu tohoto slova, jež se používalo ve smyslu osoby v právním smyslu, k označení sociální role člověka, jeho charakteru či k označení filozofického pojmu osoba. ${ }^{11}$ Podle Jana Hurdíka se „výraz persona současně zevšeobecňuje a vyjadřuje zásadně lidské individuum vybavené rozumem". 12

Je však potřeba mít na paměti, že pojem osoby v antice nijak nekoresponduje s abstraktním pojetím osob v právním smyslu v dnešní době, a to at' osob fyzických nebo právnických. Přestože se může na první pohled zdát, že výraz persona měl v antickém Římě dvojí význam - první by zahrnoval všechny svobodné lidi i otroky, druhý pak pouze osoby v právním smyslu, tedy pouze svobodné lidi - není tomu tak. Dokazuje to skutečnost, že římský právník Gaius ve své Učebnici práva ve čtyřech knihách (Institutionum comentarii quattuor) v části věnované právnímu postavení lidí (De condicione hominum) uvádí následující: „A základní rozdělení práva osob je tedy takové, že všichni lidé jsou bud' svobodní, anebo otroci. "13 Dále pak hovoří o persona servilis nebo persona servi. ${ }^{14}$ To samozřejmě není v rozporu s tím, že Gaius otroky zařazuje mezi res corporales (věci hmotné), otrok byl zároveň osobou i věcí. Otroci byli nadáni určitými právy - ř́mské právo znalo např́klad institut peculium, na základě něhož mohli otroci spravovat určitý majetek, který jim svěřil pater familias. Otroci byli zároveň objektem právních vztahů, mohlo s nimi být

8 HURDÍK, J. Pojem osoba a geneze jeho obsahu jako základ konstrukce osob v právním smyslu. Časopis pro právní védu a praxi, 2000, č. 3, s. 307.

$9 \quad$ HURDÍK, Osoba a jeji soukromoprávni postavení v měnícím se světě, s. 20.

10 ŠEJVL, M. Subjekt práva jako maska. In: HAVEL, B. - PIHERA, V. (eds.). Soukromé právo na cestě: eseje a jiné texty k jubileu Karla Eliáše. Plzeň: Vydavatelství a nakladatelství Aleš Čeněk, 2010, s. 314-327.

BERAN, Pojem osoby v právu, s. 13.

HURDÍK, Pojem osoba a geneze jeho obsahu jako základ konstrukce osob v právním smyslu, s. 308.

V originále Gai 1, 9: Et quidem summa divisio de iure personarum haec est, quod omnes homines aut liberi sunt aut servi. KINCL, J. Gaius: Učebnice práva ve čtyřech knihách. Plzeň: Aleš Čeněk, 2007, s. 42-43.

14 Gai 1, 121; 3, 189; Tamtéž, s. 72, 232. 
obchodováno jako s jinými věcmi. ${ }^{15}$ Určitou zajímavostí je, že ve starověkém Římě byly chrámy a jiné náboženské a státní instituce nadány určitou formou právní subjektivity, a to z toho důvodu, že tyto subjekty byly odpojeny od ,ducha člověka“. ${ }^{16}$

Podle mého názoru nemůžeme pojem persona $\mathrm{z}$ antického období ztotožňovat s dnešním pojmem osoby v právním smyslu, tento pojem byl v tehdejší době mnohoznačný a pravděpodobně neměl žádný právně-technický význam. Souhlasím tedy s Karlem Beranem, který ř́íá, že ,starověká a současná koncepce pojmu osoby nemají téměř nic společného“. ${ }^{17}$ Pro tvrzení Jana Hurdíka hodnotícího antické období tak, že „lze v současné právnické literatuře a právnické terminologii spatřovat výrazná rezidua kořenů, z nichž pojem osoba historicky vyrůstal“ ${ }^{18}$ nenacházím oporu. Tento výklad lze tedy uzavrrít tak, že v době antiky sice došlo k formování pojmu osoba ve smyslu lidského individua vybaveného rozumem, nicméně nelze přeceňovat význam tohoto vývoje pro dnešní konstrukt osoby v právním smyslu.

\subsection{Pojem osoba v raném a vrcholném středověku}

Nový impuls k vývoji vnímání pojmu osoba přišel možná poněkud nečekaně v období raného a vrcholného středověku. Podle Jana Hurdíka dochází v tomto období „k všeobecnému přijetí pojmu osoba jako obecné charakteristiky vyjadřující sice lidské vlastnosti, avšak na natolik schematické a obecné úrovni, které umožnily pojem osoba - vybavený specificky tomuto pojmu přiznanými vlastnostmi - osamostatnit od jeho původního nositele, tj. člověka, a formulovat jej jako samostatnou myšlenkovou konstrukci a následně jako entitu, která byla schopna stát se činitelem z nejvýznamnějších, tj. subjektem společenských, resp. právních vztahů bez ohledu na to, zda je přímo spojena s lidskou biosociální existencí či nikoliv“. ${ }^{19}$

Středověké chápání osoby bylo ovlivněno křest’anskou teologií, která tento pojem obohatila tím, že označovala trojjediného Boha jako jedinou božskou substanci (tres personae, una substantia). Karel Beran uvádí, že „osoba je tedy konfrontována se svou podstatou (substantia) a představuje transformovanou jevovou podobu jediné božské substance“". ${ }^{20}$ Jan Hurdík dodává, že se ,, k křest’anském učení o Svaté trojici pojmu osoba užívá k označení jedince existujícího sama o sobě, dále neredukovatelného a vymezeného vůči okolnímu prostředí“. ${ }^{21}$

Vývoj pojmu osoba trvale ovlivnil křest’anský teolog a filozof Boëthius touto definicí: „Osoba je individuální substance rozumové přirozenosti.“22 K tomu dodává, že základním elementem definice osoby je autonomie. Zároveň však říká, že „Otec je otcem někoho, Syn

15 HOVEN VAN GENDEREN, R. van den. Legal personhood in the age of artificially intelligent robots. In: BARFIELD, W. - PAGALLO, U. (eds.). Research Handbook on the Law of Artificial Intelligence. Camberley, Surrey: Edward Elgar Publishing Limited, 2018, s. 218.

Tamtéž, s. 221.

BERAN, Pojem osoby v právu, s. 16.

HURDÍK, Pojem osoba a geneze jeho obsahu jako základ konstrukce osob v právním smyslu, s. 308.

HURDÍK, Osoba a jeji soukromoprávni postavení v měnícím se světě, s. 21.

BERAN, Pojem osoby v právu, s. 16.

HURDÍK, Pojem osoba a geneze jeho obsahu jako základ konstrukce osob v právním smyslu, s. 308.

FAIRWEATHER, E. R. A Scholastic Miscellany: Anselm to Ockham. Philadelphia: Westminster John Knox Press, 1956, s. 334. 
je synem někoho a Duch je duchem někoho“, 23 čímž zdůrazňuje vedle autonomie vztahovou rovinu pojmu osoba, samozřejmě pouze v mezích výkladu o Svaté trojici.

Nejasnosti v otázce, jestli má být osoba charakterizována pouze v dimenzích substance, nebo v dimenzích vztahu, se pokusil odstranit jeden z nejvýznamnějších křest’anských filozofů Tomáš Akvinský, který přichází s pojmem „subsistentní vztah“, nicméně opět pouze ve vazbě na Svatou trojici. V př́padě lidí naopak v pojmu osoba vztahový prvek odmítá, protože ,„podstatou Boha je komunikabilita, podstatou člověka je nekomunikabilita“. ${ }^{24}$ Podle Jana Hurdíka dále Tomáš Akvinský v souvislosti s osobou užívá pojmu subjekt, který ztotožňuje se substancí a který nabývá různých významů v závislosti na konkrétnosti jeho posuzování. Je-li subjekt chápán jako rozumová substance, je nazýván osobou. Tyto závěry Akvinského směřují k modernímu pojetí osoby ve smyslu sebeuvědomění a odpovědnosti za své vlastní činy. ${ }^{25}$

Jan Hurdík uzavírá, že ve výše uvedených závěrech křest’anských myslitelů jsou definovány všechny obecně přijímané znaky osoby v právním smyslu. ${ }^{26} \mathrm{~S}$ tímto závěrem nesouhlasí Karel Beran, který ř́ká, že se vliv středověké teologie a dogmatiky „na abstraktní pojem osoby v právním smyslu přeceňuje“. ${ }^{27} \mathrm{~S}$ tímto názorem se ztotožňuji, nebot' se dosud nepodařilo prokázat, jestli se opravdu jedná o abstraktní koncepci osoby, nebo jde spíše o antropomorfní smýšlení tehdejších lidí. Pro starověk i středověk bylo typické, že nadpřirozeným bytostem lidé přisuzovali lidské vlastnosti, Bohu a svatým tak byla přiznána právní subjektivita. Za bytosti byly dokonce považovány stromy, zvířata či předměty denní potřeby, ${ }^{28}$ což je dnešnímu konceptu osoby velmi vzdálené.

Křest’anskému myšlení je také vlastní myšlenka duchovního rozměru osoby. V náboženských textech najdeme často odkazy na to, že osoba je definována „přítomností duše“. Podle Katechismu katolické církve je slovo „duše“ definováno následovně: „Duše znamená duchovní princip v člověku.“ Duše se dále považuje za základ lidského vědomí a svobody. Svoboda rozhodování je pak etickým a právním základem odpovědnosti, kterou jsme jakožto přirozené bytosti nadáni. ${ }^{29}$

Středověké křest’anství přišlo ještě s jedním významným konceptem - tzv. corpus mysticum, což lze chápat jako společenství věřících. Tehdejší významný právník Sinibaldus Fliscus (později papež Innocens IV.) si všiml, že když došlo k nějakému majetkovému sporu mezi církevními řády nebo úřady, žalobce druhý subjekt žaloval vždy jménem církve. Přišlo mu nelogické, že na obou stranách sporu stojí tentýž subjekt, a tak přišel s konceptem, kdy právní subjektivitu přiznal nejen církvi jako takové, ale i církevním úřadům,

ZICCARDI, M. J. Fundamental Boethius: A Practical Guide to the Theological Tractates and Consolation of Philosophy. Lulu Press, Inc, 2012, second tractate.

24 V anglickém překladu De potentia je uvedeno následující: „The word person signifies one that subsists in the divine nature distinctly and incommunicably: whereas the word God signifies one who has the divine nature without reference to distinction or incommunicability: hence the comparison fails." AKVINSKÝ, T. De potentia, $I X$, The divine persons “. [online]. Dostupné na: https://dhspriory.org/thomas/QDdePotentia9 .htm. [cit. 25. 01. 2019].

25 HURDÍK, Osoba a jeji soukromoprávní postavení v měnícím se světě, s. 22.

26 HURDÍK, Pojem osoba a geneze jeho obsahu jako základ konstrukce osob v právním smyslu, s. 309.

27 BERAN, Pojem osoby v právu, s. 17.

28 BYDLINSKI, Die „Person“ im Recht, s. 81.

29 HOVEN VAN GENDEREN, van den, Legal personhood in the age of artificially intelligent robots, s. 221. 
a dokonce i církevním statkům. ${ }^{30}$ Zde můžeme zřetelně vidět kořeny moderní konstrukce právnických osob.

\subsection{Pojem osoba v raném novověku}

Pro další vývoj pojmu osoba v právním smyslu byl významný koncept tzv. morální osoby. Pojednání o tomto konceptu musíme začít u významného německého právního teoretika, žijícího v letech 1632-1694, Samuela von Pufendorfa. Jeho dílo De iure naturae et gentium libri octo z roku 1672 se obecně považuje za základ, z něhož vychází pozdější pojetí pojmu morální osoby. Samuel von Pufendorf však nechápal morální osobu jako pozdější právní doktrína (tedy výhradně jako sdružení osob), nýbrž tento pojem vztahoval k jedinci ,jjako jednu z forem morálních jsoucen“. ${ }^{31}$ Sociální status člověka určuje to, jaké má morální povinnosti, a podle toho, jak se mu daří tyto povinnosti plnit, je morální osobou. Pojem morální osoby však má podle Samuela von Pufendorfa i druhý význam zahrnující skupinu osob. Osoby sdružené v této složené morální osobě však nesledovaly žádný společný cíl, spojoval je pouze společný status, takže v tomto případě nemůžeme hovořit o analogii s moderním pojetím právnické osoby. Pufendorf navázal na myšlenky Thomase Hobbese, který ve svém díle Leviathan osobu definoval takto: „Osobou je ten, jehož slova nebo činy jsou považovány bud' za jeho vlastní, nebo jsou přičítány jinému člověku nebo jakékoli jiné věci, at' už skutečně, nebo fikcí. Pokud jsou tato slova a činy považovány za jeho vlastní, pak se nazývá fyzickou osobou. Pokud jsou přičítány někomu jinému, hovoříme o předstírané nebo umělé osobě. "32 Thomas Hobbes tedy také rozlišoval dvě kategorie osob, byt' jim nepřisuzoval aspekt morality, jako tomu bylo v př́ípadě Pufendorfa.

Další osobností, která přispěla k rozvoji konceptu morální osoby, byl německý filosof Christian Wolff žijící v letech 1679-1754. Christian Wolff opustil koncept morálního jsoucna a jako výchozí bod svých úvah určil morálního člověka (homo moralis). Podle něj morální stav (resp. status), který morální člověk získává (tím se neliší od Samuela von Pufendorfa), již není na rozdíl od Pufendorfovy teorie externím objektivním prvkem, ale určitým subjektivním závazkem a oprávněním. Nicméně morální status nevytváří z člověka osobu v právním smyslu, ale pouze ve smyslu konkrétních práv a povinností. ${ }^{33}$ Christian Wolff zároveň ř́ká, že každý člověk má základní přirozenou povinnost zachovat svůj vlastní život, kterou nazývá obecnou obligací (obligatio universalis). Z dodržování této povinnosti dovozuje morálnost člověka. Tento přístup je rozdílný od dnešní koncepce lidských práv, kdy je právo na život výhradně právem, nikoliv povinností. Christian Wolff nicméně z povinnosti morálního člověka dovozuje, že člověk má zároveň právo žít, z toho plyne i minimální rozsah práv, která může požadovat po svém okolí a která nejsou již vyvozována z vnějšku, nýbrž právě z přirozenosti morální osoby. ${ }^{34}$ Jelikož Christian Wolff přisuzuje osobě univerzální obligaci zachovat svůj život, ani u něj nenalezneme paralelu

30 BERAN, Pojem osoby v právu, s. 18.

31 PUFFENDORF, Samuel von. De iure naturae et gentium libri octo. Frankfurt - Leipzig, 1759, lib. I cap. I § XII-XIII; převzato z: BERAN, K. Kdy a proč byla nahrazena „osoba“ právním subjektem? Časopis pro právni védu a praxi, 2011, č. 2, s. 113.

32 HOBBES, T. Hobbe's Leviathan. Oxford: Clarendon Press, 1929, s. 123.

33 WOLFF, Ch. Jus naturae. Frankfurt, 1740; převzato z: BERAN, Pojem osoby v právu, s. 24.

34 Tamtéž; převzato z: BERAN, Kdy a proč byla nahrazena „osoba“ právním subjektem?, s. 113. 
k modernímu pojetí právnických osob, právní subjektivitu přiznává pouze jednotlivcům lidem.

O zásadnější posun ve vnímání pojmu morální osoby se v 18. století zasadil německý právník a filozof Daniel Nettelbladt (žijící v letech 1719-1791), který v roce 1749 vydal významné dílo Systema elementare universae iurisprudentiae naturalis. Význam jeho díla spočívá v tom, že již rozlišuje „osobu přirozenou“ a „osobu morální“. Člověk je na jedné straně označen jako přirozená osoba, zároveň s tím je ale i osobou v právním slova smyslu jakožto homo moralis. Právní postavení osoby pak vyplývá ze statusu člověka. Představa člověka jako subjektu práv a povinností se stává samozřejmostí. Nettelbladt dále jako morální osobu vnímá, na rozdíl od Christiana Wolffa, také sdružení osob. Individua sdružená v takové morální osobě sice stále spojoval na základě sdílení společného statusu, takže morální osobě v jeho pojetí stále nemůžeme přiznat právní subjektivitu v dnešním slova smyslu, společný status se však již začínal nenápadně projevovat prosazováním společného cíle sdružených osob. ${ }^{35}$ Morální osoba ve smyslu sdružení osob má podle něj reálný obsah, resp. vlastní právní kvalitu projevující se právy a povinnostmi odlišnými od práv a povinností jednotlivých osob. ${ }^{36}$ Tento aspekt vnímám jako velký pokrok v chápání pojmu právnické osoby.

Na základě výše uvedeného můžeme tuto část uzavřít tak, že Samuel von Pufendorf, Christian Wolff i Daniel Nettelbladt významně přispěli k rozvoji chápaní osoby v právním smyslu. Zatímco Samuel von Pufendorf ještě vnímal morální osobu jako jednu z forem morálních jsoucen, Christian Wolff morálnost člověka odvozoval z dodržování povinnosti zachovat vlastní život, z čehož pro člověka plyne i minimální rozsah práv, která může požadovat po svém okolí. Vývoj završil Daniel Nettelbladt, který každého člověka chápe jako osobu v právním smyslu - homo moralis. Zároveň v jeho myšlenkách spatřujeme zárodky moderního pojetí právnické osoby, projevující se tím, že sdružením osob přiznával práva a povinnosti odlišné od práv a povinností jednotlivých osob, které takové sdružení tvoří.

Všem třem výše uvedeným myslitelům je společné statusové pojetí osoby. Jak uvádí Karel Beran, tomuto období ,je ještě cizí dělení osobnostního a majetkového práva, všechno právo je osobnostní právo a je projevem toho či onoho statusu“. ${ }^{37}$ Díky statusu se člověk stává osobou v právním slova smyslu a náleží mu osobnostní a majetková práva. Při změně statusu člověk některá nová práva získal, jiná zase ztratil. Statusová nauka je tedy pozůstatkem feudálního práva, kdy se právní subjektivita odvozovala od př́slušnosti ke stavu (napřr. šlechta, duchovenstvo, měšt’ané), prŕílušníci jednotlivých stavů disponovali rozdílnými právy a povinnostmi. Podle Jana Hurdíka je starověké a středověké období typické ,,apriorní nesvobodou jednotlivce, apriorní nerovností jednotlivce, akceptací společenských diferencí a jejich fixace právem, a pozicí jednotlivců budované zpravidla na vzájemně aktivní pozitivní míře integrace jednotlivce do určité společenské skupiny““.38 Dokud byly práva a povinnosti člověka odvozovány od jeho statusu, nemohla se prosadit myšlenka univerzální právní subjektivity všech lidí. Zásadní zlom přináší racionalismus

35 NETTELBLADT, D. Systema elementare universae iurisprudentiae naturalis. Halle - Magdeburg, 1767 , $\S 43$; převzato z: BERAN, Kdy a proč byla nahrazena „osoba“ právním subjektem?, s. 113-114.

36 Tamtéž; převzato z: BERAN, Pojem osoby v právu, s. 24.

37 BERAN, Kdy a proč byla nahrazena „osoba“ právním subjektem?, s. 114.

38 HURDÍK, Osoba a jeji soukromoprávní postavení v měnícím se světě, s. 30. 
vrcholného novověku, kdy „pojem osoba dostává nový dominantní význam, který je založen na chápání osoby jako obrazu lidské bytosti, jako výrazu pro označení člověka ve smyslu sebeuvědomělého subjektu, odpovědného za své činy, aktivního tvůrce dějin“.39

Podíváme-li se na pojem osoba v raném novověku v českých zemích, typické bylo samozřejmě také statusové pojetí osoby. Př́islušnost ke stavu se „dědila“ po otci při narození dítěte, nicméně i přesto existovala určitá možnost sociální mobility, byt' hodně omezená. Kupříkladu nevolník se mohl stát za určitých podmínek měšt’anem, měšt’an př́islušníkem šlechty na základě rozhodnutí krále atp. Ke změně sociálního statusu mohlo dojít také sňatkem, přičemž níže postavená žena získala status výše postaveného manžela. V případě, že si výše postavená žena vzala níže postaveného muže, svůj původní status sňatkem ztratila. ${ }^{40}$

Velkou roli hrála také čest, jejíž ztráta měla fatální právní i společenské důsledky. Čest bylo možné ztratit při chování, které odporovalo společenským pravidlům, např. při zradě, nekřest’anském způsobu života, porození nemanželského dítěte apod. Trest ztráty cti byl rovněž ukládán při spáchání některých zločinů. Některé společenské skupiny lidí ale byly bezectné samy o sobě, šlo např́iklad o katy, rasy a jejich pomocníky, komedianty, tuláky, žebráky nebo prostitutky. Dřive ztracenou čest bylo možné nabýt na základě rozhodnutí soudu nebo královy milosti. K takové osobě se nikdo nemohl chovat jako k osobě nečestné, dokonce bylo zakázáno tuto jejich minulost jakýmkoliv způsobem připomínat. Porušení tohoto pravidla bylo př́isně trestáno. ${ }^{41}$

\subsection{Pojem osoba ve vrcholném novověku}

Na začátku této pasáže musím alespoň stručně připomenout odkaz francouzského filozofa Reného Descarta (1596-1650). Přestože se narodil dříve než tři výše zmínění myslitelé, jeho myšlenky svým způsobem předběhly dobu. René Descartes, známý svým citátem Cogito ergo sum (Myslím, tedy jsem), měl ,zásadní vliv na přijetí pojmu osoby jako sebeuvědomělého individua, jako myslící bytosti, kterážto vlastnost je základem jeho existence“. ${ }^{42}$ Postupem tzv. metodické skepse dochází k tomu, že každý jedinec může pochybovat o všem, co předpokládá nebo zná. Člověk si nemůže být jistý, jestli předmět, o kterém přemýšlí, skutečně existuje, či zda jsou jeho úvahy pravdivé nebo chybné. „Avšak at' je lidské myšlení pravdivé či chybné, člověk myslí. Realita, o kterou člověk opírá svou existenci, je realitou myšlení.“43 Podle Reného Descarta se jako subjekt (osoba) kvalifikuje ten, kdo myslí. Doslova říká, že výpověd’, ,já jsem, já existuji, je nutně pravdivá, kdykoli ji pronesu, nebo pojmu myslí‘. 44

Jedním z nejvýznamnějších evropských filozofů vrcholného novověku byl bezpochyby Immanuel Kant (1724-1804). Ten ve svém díle Základy metafyziky mravů zřejmě jako první rozporuje paradigma, že sociální status člověka je hlavním determinantem jeho práv

39 HURDÍK, Pojem osoba a geneze jeho obsahu jako základ konstrukce osob v právním smyslu, s. 310.

40 KNOLL V. Legal personality of natural persons in the Czech medieval private law. Brief Summary. Journal on European History of Law, 2010, č. 1, s. 59-61.

41 Tamtéž.

42 HURDÍK, Pojem osoba a geneze jeho obsahu jako základ konstrukce osob v právním smyslu, s. 310.

43 Tamtéž.

44 DESCARTES, R. Meditationes de prima philosophia. Překl. MARVAN, T. - GLOMBÍČEK, P. Praha: Oikoymenh, 2001, s. 28. 
a povinností. Immanuel Kant musel svou revoluční myšlenku rovnosti před zákonem podepř́t metafyzickým vysvětlením rovnocenného statusu všech lidí. Immanuel Kant o osobě hovoří jako o cause finalis, tedy jako o entitě svého vlastního cíle. Tato skutečnost odlišuje osobu od věcí a pojmů, které slouží jako prostředky k dosažení cíle. Osoby jsou rozumnými existencemi, jsou dílem samy o osobě, ze své vlastní podstaty. Rozumová podstata uvádí osobu do pozice cíle sama o sobě. Každá osoba je způsobilá stanovit si cíle svého jednání a je vlastním subjektem všech myslitelných cílů.

Immanuel Kant uvádí, že má-li ,existovat nejvyšší praktický princip, který je vzhledem k lidské vůli kategorickým imperativem, musí to být takový, který z představy toho, co je nutně účelem pro každého, poněvadž je to účel sám o sobě, tvoří objektivní princip vůle, a proto může sloužit za obecný praktický zákon“. 45 A dále: „Základem tohoto principu je to, že rozumná přirozenost existuje sama o sobě jako účel. Tak si nutně člověk představuje své vlastní jsoucno, potud je tedy ono subjektivním principem lidského jednání. Ale právě tak si v důsledku téhož rozumového důvodu, který je platný i pro mne, představuje své jsoucno každá jiná rozumná bytost, takže je to zároveň i objektivní princip, z něhož, jako z nejvyššího praktického základu, musí být odvoditelné všechny zákony vůle. Praktický imperativ lze tedy formulovat takto: jednej tak, abys používal lidství jak ve své osobě, tak i v osobě každého druhého vždy zároveň jako účel a nikdy pouze jako prostředek. "46

Immanuel Kant tak povýšil pozici každého člověka do říše svých vlastních účelů a každému člověku přiznává důstojnost a jeho vlastní hodnotu. „V řriši účelů má vše bud’ nějakou cenu, nebo důstojnost. Namísto toho, co má cenu, lze klást i něco jiného jako ekvivalent, ale to, co je naproti tomu povzneseno nad jakoukoli cenu, a co proto nepřipouští žádný ekvivalent, má důstojnost... Pouze důstojnost lidství jako rozumné přirozenosti, bez jakéhokoliv jiného účelu či prospěchu, jehož by tím bylo možno dosáhnout, a tedy neúcta $\mathrm{k}$ pouhé ideji, by měla být neprominutelným předpisem vůle, a že právě v nezávislosti maximy na všech takových pružinách záleží její vznešenost, stejně jako výsadní důstojnost každého rozumného subjektu být zákonodárným členem v říši účelů. “47 Kant akceptoval u pojmu osoba její morální kvalitu a současně její individuální rozměr. Osobu nazývá rozumnou substancí, za její cíl označuje humanitu. Osoba je pro Kanta totožná s vnitřní svobodou, způsobilou si stanovit vlastní zákony, jejichž prostřednictvím dosahuje svých cílů. V tomto smyslu Kant nazývá osobu morálním subjektem, hodným respektu.

Podle Immanuela Kanta má tak každý člověk, jakožto účel sám o sobě, svou vnitřní hodnotu, tj. důstojnost. Důstojnost podle něj spočívá v autonomii (svobodě) vůle, kterou však chápe v mezích zákonných pravidel, jimž každá osoba podléhá. Důstojnost vysvětluje hlavně jako lidskost, která je integrální součástí každé osoby. Karel Beran Kantovo učení shrnuje tak, že „když Kant dovodil, že člověk by měl být svým vlastním účelem a nikoliv prostředkem k dosahování účelů cizích, zároveň tím také řekl, že člověk má přirozené právo na uznání své osobnosti, které je založené v ní samotné. Tím byl definitivně překonán koncept, podle kterého náleží člověku morální osobnost v návaznosti na jeho sociální status. Pro Kanta již morální osoba nepředstavuje právní termín, nýbrž znamená vyjádření svobody člověka vázaného mravním zákonem“. ${ }^{48}$ Jak je uvedeno v dalším textu, Franz von

\footnotetext{
45 KANT, I. Základy metafyziky mravi̊. 2. vyd. Praha: Svoboda, 1990, s. 91.

46 Tamtéž.

47 Tamtéž, s. 97, 101.

48 BERAN, Pojem osoby v právu, s. 31.
} 
Zeiller byl při koncipování právního postavení osob v ABGB ovlivněn zejména Kantovým pojetím lidské důstojnosti.

Německý filozof Georg Wilhelm Friedrich Hegel (1770-1831) obohatil pojem osoba o atribut společenského vztahu. Hegel tak překonal Kantův individualismus, protože podle něj autonomie jednajících subjektů nemůže mít apriorní povahu. Individualizace je proces probíhající současně se socializací. Ani osoba není pro Hegela žádný ideální apriorní model, nýbrž představuje výsledek procesu probíhajícího v rámci souboru společenských vztahů, jichž se osoba účastní. 49

Hegel ke vztahu svobody a společenských vztahů uvádí toto: „Svoboda, kterou zde máme, je to, co nazýváme osobou, tj. subjektem, který je svobodný, a to pro sebe svobodný, a který si dává jsoucno ve věcech. Tato pouhá bezprostřednost jsoucna však svobodě není přiměřená a negace tohoto určení je sféra morality. Už nejsem svobodný pouze v této bezprostřední věci, nýbrž jsem svobodný také v překonané bezprostřednosti, to znamená jsem svobodný v sobě samém, v subjektivnu. V této sféře záleží na mém úsudku a úmyslu a na mém účelu, zatímco vnějškovost je kladena jako bez rozdílu. “50

V tento okamžik svobodu jedince podle Hegela omezuje existence společenských vztahů. Hegel uvádí, že v prŕpadě rodiny individuum ,ppřekonalo svou nepoddajnou osobnost a nachází se v jednom celku se svým vědomím. Avšak na dalším stupni je vidět ztrátu vlastní mravnosti a substanciální jednoty: rodina se rozpadá a jednotlivé články se k sobě navzájem chovají jako samostatné, poněvadž je obepíná pouze pouto vzájemné potřeby. Tento stupeň občanské společnosti byl často pokládán za stát. Ale stát je teprve to třetí, mravnost a duch, v němž se uskutečňuje neobyčejné sjednocení samostatnosti individuality a obecné substanciality. Právo státu je proto vyšší než ostatní stupně: je to svoboda ve svém nejkonkrétnějším ztvárnění, které spadá jen ještě pod nejvyšší absolutní pravdu světového ducha“".51

Pro Hegela je při definování osoby významný, podobně jako pro Descarta, rozum jedince, resp. jeho sebeuvědomění. Hegel říká, že „osobnost začíná teprve tam, kde subjekt má nejen sebevědomí vůbec o sobě jakožto o konkrétním, nějakým způsobem určeném Já, nýbrž spíše sebevědomí o sobě jakožto o naprosto abstraktním Já, v němž je veškerá konkrétní ohraničenost a platnost negována a neplatná. V osobnosti je proto vědění sebe jakožto předmětu, ale jakožto předmětu povýšeného myšlením do jednoduché nekonečnosti, a tím čistě identického se sebou“. 52

Zejména Kantovy myšlenky vytvořily prostor pro oddělení práva a morálky, což využil především německý právník Friedrich Carl von Savigny (1779-1861), který o právu ř́íá, že je ,vytvořeno za účelem zajištění svobody k mravnímu jednání a jeho podstata je tedy odlišná od morálky“, a dodává, že „,každý člověk je proto osobou ve smyslu subjektu práva“. 53 Od Savignyho doby je právo chápáno jako prostředek k naplnění morálního zákona. Friedrich Carl von Savigny navíc zdařile definuje i právní subjektivitu, resp. osobu v právním smyslu: „Zde se tedy klade otázka: kdo může být osobou v právním smyslu, tedy nositelem nebo subjektem právního vztahu? Tato otázka se týká možnosti mít práva nebo způsobilosti k právním jednáním. Proto se musí původní pojem osoby nebo práv-

49 LAVICKÝ, Občanský zákonik I. Obecná část (\$ 1-654). Komentář, s. 129.

50 HEGEL, G. W. F. Základy filosofie práva. Praha: Academia, 1992, s. 71-72.

51 Tamtéž, s. 72.

52 HEGEL, Základy filosofie práva, s. 74.

53 SAVIGNY, F. C. System des heutigen Römischen Rechts. Bd. 2. Berlin: Veit, 1840, s. 2. 
ního subjektu shodovat s pojmem člověka a tato původní identita obou pojmů může být vyjádřena následující definicí: každý jednotlivý člověk a právě pouze jednotlivý člověk je právně způsobilý. " 54

Diferenciace mezi člověkem jako morální osobou a právním subjektem byla nutným předpokladem k modernímu abstraktnímu pojetí pojmu osoba v právním smyslu. Subjektivita se konečně stala pouze právním pojmem v budoucnu použitelným jak pro fyzické osoby (resp. v terminologii Daniela Nettelbladta přirozené osoby), tak pro osoby právnické. Později sám Friedrich Carl von Savigny připouští, že se uměle vytvořené entity mohou stát nositeli subjektivních práv a povinností a tyto entity označuje jako juristische Personen (právnické osoby). ${ }^{55}$

I nadále zůstalo chápání právní subjektivity spojeno s problematikou svobodného mravního jednání člověka, ale samo o sobě nepředstavovalo již morální, nýbrž ryze právní kategorii. Etické bytí člověka vyžaduje obecnou způsobilost k právům a povinnostem, aniž by ji tím však posouvalo do morální roviny, jako tomu bylo v prrípadě přirozenoprávních pojetí. Tuto tezi můžeme shrnout tak, že ,právní subjektivita je tak pouze předpokladem pro to, aby byl člověk způsobilý si v právní rovině stanovit vnější hranice, které mu umožní svobodný rozvoj jeho morální osobnosti“".56

Savignyho obdivuhodný myšlenkový vývoj dokládá skutečnost, že ve svém nejvýznamnějším díle System des heutigen römischen Rechts nakonec dospěl i ke zdařilému vymezení pojmu právnické osoby: „Používám tedy pouze pojem právnická osoba (vůči které je opakem přirozená osoba, tj. jednotlivý člověk) k tomu, abych vyjádřil, že tato osoba existuje pouze pro účely práva. Dříve se běžně používalo pojmu morální osoba, který odmítám jednak proto, že vůbec nesouvisí s mravními nebo morálními poměry takové osoby, a také proto, že je takový pojem vhodný spíše k tomu označovat mezi lidmi protiklad nemorálního člověka, takže tento název zavádí myšlenky na zcela jiné oblasti. Samotní Rímané neměli společné označení pro všechny tyto subjekty, pouze tvrdili, že mají podobný charakter jako osoby, byt' šlo o fiktivní entity. “57

Friedrich Carl von Savigny je tak prvním právníkem, který chápal pojem osoba v právním smyslu podobně jako dnešní právní doktrína. Přestože někteří jeho kolegové používali pojmu právnické osoby dříve, ${ }^{58}$ zaměňovali jej s pojmem morální osoby. Průlomem tak byla až Savignyho definice uvedená výše.

Pojetí osob v právním smyslu bylo v rakouské doktríně poznamenáno střetem Kantovy a Hegelovy filozofie. ${ }^{59}$ Redaktoři rakouského zákoníku (zejména Franz von Zeiller) vychá-

54 Tamtéž, s. 1.

55 Tamtéž, s. 240-241.

56 LIPP, M. „Persona moralis“, ,juristische Person“ und „Personenrecht“ - eine Studie zur Dogmengeschichte der ,juristischen Person“ im Naturrecht und frühen 19. Jahrhundert. Quaderni fiorentini per la storia del pensiero giuridico moderno, 1982/83, 11/12, s. 259.

57 SAVIGNY, System des heutigen Römischen Rechts, s. 240-241.

58 Prvenství v použití výrazu ,právnická osoba“ je připisováno Gustavu Hugovi a jeho dílu Lehrbuch des Naturrechts als einer Philosophie des positiven Rechts z roku 1798, někdy je však uváděn Georg Arnold Heise a jeho publikace Grundriß eines Systems des allgemeinen Civilrechts zum Behuf von Pandekten-Vorlesungen z roku 1807.

59 ANDRES, B. - HARTMANN, A. - ROUČEK, F. - SEDLÁČEK, J. Komentář k československému obecnému zákoníku občanskému a občanské právo platné na Slovensku a v Podkarpatské Rusi. Díl 1, (\$§ 1 až 284). Repr. pův. vyd. z r. 1935. Praha: Codex Bohemia, 1998, s. 181-182, 250. 
zeli z Kantových myšlenek, což je patrné zejména na formulaci § 16 ABGB. Každý člověk má svou vnitřní hodnotu, tj. důstojnost. Důstojnost spočívá zejména v autonomii vůle, která je chápána v mezích zákonných pravidel, jimž každá osoba podléhá. Každý člověk má zároveň přirozené právo na uznání své osobnosti, které je založené v ní samotné. Tím bylo definitivně překonáno statusové pojetí právní osobnosti. Rakouská právní doktrína v druhé polovině 19. století naproti tomu vnímala osobu spíše z pohledu Hegela. Tento pohled upozad'uje Kantův individualismus a pojem osoba vykládá jako výsledek procesu probíhajícího v rámci souboru společenských vztahů, jichž se osoba účastní. Autonomie jednajících subjektů nemůže mít apriorní povahu, individualizace je totiž proces probíhající současně se socializací.

\subsection{Pojem osoba v moderních dějinách}

Do chápání pojmu osoba zasáhla sociologie, která se jako samostatná vědní disciplína zformovala na počátku 19. století. Sociologie založila své studium osoby a společnosti na kritickém postoji ke Kantovu individualismu a Hegelovu vnímání společenského vztahu jako zásadní dimenze existence osoby. Zakladatel moderní sociologie Émile Durkheim chápal osobu jako výslednici dvou faktorů působících vzájemně protikladně: faktoru socializace a faktoru individualizace. Durkheim přitom zdůrazňuje faktor socializace, nebot' osoba se podle něj stává individuem až v procesu své interakce se sociálním prostředím. ${ }^{60}$

Durkheim říká, že i když společenské jevy vznikají z přímé spolupráce lidí, nejsou jejich pouhým součtem, ale výslednicí společného života, výtvorem akcí a reakcí mezi jednotlivými vědomími. ${ }^{61}$ Společnost je tedy více než suma částí - jednotlivců - a navíc taková suma, která je s to vykonávat na své jednotlivé součásti nátlak. Společenské jevy jsou druhy jednání, myšlení a cítění, které existují mimo individuální vědomí, a navíc se jedinci vnucují. To si individuum nemusí uvědomovat pořád, tlak se však projeví pokaždé, jakmile se pokusí o odpor. Existenci společenského nátlaku vysvětluje Durkheim autonomií společnosti a jejích jednotlivých částí a jejich trvalostí. ${ }^{62}$ Durkheim tvrdil, že „kolektivní druhy jednání nebo myšlení mají svou skutečnost mimo jedince, kteří se jim v každé době přizpůsobují. Jsou to věci, které mají svou vlastní existenci. Jedinec je nalézá zcela hotové." 63 To neznamená, že se všichni lidé musí chovat absolutně stejně. Jedinec si společenská pravidla může přizpůsobit - ale jen do té míry, která je společností tolerována.

Durkheim se obrací proti představě individualismu lidské aktivity. Ta podle jeho názoru nemůže být nikdy zbavena všech brzd. Nic na světě nemůže mít takové privilegium. Protože každá bytost je součástí světa, a proto je na zbytek světa vázána. $V$ tom se neživá př́roda neliší od př́rody živé. Pro člověka je však charakteristické to, že brzdy nejsou fyzické, nýbrž morální, tedy společenské. ${ }^{64}$ Durkheim také varuje před vzrůstem individualismu, který může v konečném důsledku přerůst až v kult svobody: „Ujišt’ovat o posvátném charakteru osoby, udělat z člověka boha pro člověka, není to symbolické uctívání společnosti a integračních hodnot, které tvoří její základ? Od takového okamžiku nabývá kult osoby

\footnotetext{
60 LAVICKÝ, Občanský zákoník I. Obecná část (§ 1-654). Komentář, s. 129.

61 DURKHEIM, É. Pravidla sociologické metody. Praha: Orbis, 1926, s. 46.

62 HOLZBACHOVÁ, I. Společnost očima Emila Durkheima. Sbornik praci Filozofické fakulty brněnské univerzity. B, Řada filozofická = Studia philosophica. 2007, roč. 56, č. B54, s. 19-32.

63 DURKHEIM, Pravidla sociologické metody, s. 29.

64 HOLZBACHOVÁ, Společnost očima Emila Durkheima, s. 115.
} 
statut sociálního vztahu par excellence. Náboženství humanity, jehož dogmatem je autonomie rozumu a prvním rituálem svoboda svědomí."65

Dovolím si však tvrdit, že Durkheimova sociologie není sociologií kolektivismu. Je nepochybné, že se zabývá i zkoumáním vzniku a rozvoje nezávislého individua. Nesouhlasí ovšem s tím, co nazývá liberální fikcí, tedy s tvrzením, podle něhož na počátku dějin a společnosti stojí izolovaná a nezávislá individua, která z ničeho vytvářejí smluvní vztahy. Na druhé straně ovšem Durkheim nevidí jen světlé stránky rozvoje individualismu. Např́íklad poukazoval na to, že přehnaný individualismus vede ke zvýšení počtu určitého druhu sebevražd. Dále tvrdil, že proti individualismu nemáme bojovat, ale máme se snažit jej doplnit, rozšiŕit a organizovat, abychom dokázali organizovat hospodářský život a zavedli více spravedlnosti do smluvních vztahů. ${ }^{66}$

Některé Durkheimovy myšlenky se nepochybně projevily v komunistickém pojetí osoby, byt' Durkheim primitivní komunismus odmítal. Durkheim však koketoval se socialistickými myšlenkami, nebyl například proti zásahu do hospodářství a proti socializaci ekonomických sil. Zmiňuje se dokonce o rovnosti majetku vzniklé tím, že by byla odstraněna instituce dědictví. Konstatuje ovšem, že ani pak by nebyla odstraněna nerovnost nadání. Pro Durkheima je ovšem nejdůležitější morální stránka celé věci. Pro socialismus je podstatné, aby egoistické zájmy byly podřízeny sociálním, tj. morálním účelům. V tomto smyslu souhlasí s myšlenkou, že socialismus tenduje k tomu, aby ve společenských vztazích bylo prosazeno více spravedlnosti. Zároveň ale také vyžaduje, aby se skoncovalo s neústrojným růstem lidských ambicí - a v tomto př́ípadě vznáší požadavky i na dělnické vrstvy. $^{67}$

Na charakteristiku osoby se důsledně zaměřil personalismus. Cílem personalismu bylo poznat základ existence osoby, prričemž důraz byl kladen na komunikaci osoby. Komunikace je základem formování společenství a kolektivů, a to na základě především dlouhodobých vztahů utvářených prostřednictvím institucí, mj. prostřednictvím práva. Osoba podle personalismu neexistuje jinak než ve vztahu k jiným, nedokáže reflektovat sama sebe jinak než skrze ostatní osoby, nalézá sama sebe v osobách ostatních. Do chápání pojmu osoba promluvila také fenomenologie. Fenomenologií se zabýval např́iklad francouzsko-židovský filozof Emmanuel Lévinas, který subjektivitu chápal jako odpovědnost a na této hodnotě zakládal vztah mezi subjekty. Osoba existuje v takové míře, ve které je odpovědná. ${ }^{68}$

\subsection{Pojem osoba v obecném zákoníku občanském}

Jak vyplývá z předchozích řádků, můžeme pojem osoba v právním smyslu vnímat jako výsledek racionalistického právního myšlení, resp. přirozenoprávní teorie. Toto smýšlení spolu s idejemi osvícenství69 vedlo k potřebě systematicky uspořádat právní normy do kodexů, nebot’ do té doby bylo právo roztříštěno do mnoha pramenů i forem; nadále přetrvával i partikularismus právních norem, kdy pro každý stav platilo jiné právo. Podle

\footnotetext{
65 Tamtéž, s. 129.

66 Tamtéž, s. 130.

67 Tamtéž, s. 144.

68 LAVICKÝ, Občanský zákoník I. Obecná část (\$ 1-654). Komentářr, s. 129.

$69 \mathrm{~K}$ problematice práva v období osvícenského absolutismu blíže např. v publikaci VOJÁČEK, L. - SCHELlE, K. - KNOLL, V. České právni dějiny. 3. vydání. Plzeň: Aleš Čeněk, 2016, s. 193-220, $409-414$.
} 
Radima Seltenreicha si osvícenství „obecně právě systematické úsilí vytklo za jeden ze svých hlavních a vůdčích cílů“. ${ }^{70}$ Rovněž přirozenoprávní myšlenka neměnného práva velmi napomohla kodifikačnímu úsilí. Dalším motivem zejména v habsburské monarchii byla skutečnost, že jednotlivé země měly vlastní právní řády, což přinášelo mnohé praktické problémy. Výsledkem snahy o kodifikaci právních norem v rakouské monarchii bylo přijetí obecného zákoníku občanského z roku 1811.

Franz von Zeiller byl při koncipování právního postavení osob v ABGB ovlivněn Kantovým pojetím lidské důstojnosti. Tato lidská důstojnost je odvozena od původní lidské svobody a zahrnuje všechna vrozená práva (iura connata) s výjimkou práv získaných (iura acquisita). Důstojnost spočívá zejména v autonomii vůle, která je chápána v mezích zákonných pravidel, jimž každá osoba podléhá. Každý člověk má zároveň přirozené právo na uznání své osobnosti, které je založené v ní samotné. Tím bylo definitivně překonáno statusové pojetí právní osobnosti. I proto je v první větě $§ 16$ ABGB uvedeno, že „každý člověk má vrozená, již rozumem poznatelná práva, a nutno jej tudíž považovati za osobu“. Tím zákoník stvrzoval, že vrozená práva nejsou lidem propůjčována státem, ale náleží každému člověku z titulu jeho lidské důstojnosti. Z tohoto konstruktu vyplývá idea rovnosti všech lidí, což stvrzuje odstavec druhý § 16 takto: „Otroctví nebo nevolnictví a k tomu se vztahující výkon moci nejsou v těchto zemích dovolena." Lidská důstojnost je tak příčinou uznání osoby v právním smyslu.

Z ustanovení § 16 ABGB se odvozovala, resp. odvozuje právní osobnost (subjektivita) všech lidí. Redaktoři rakouského zákoníku tak překonali racionalistické přiznání subjektivity pouze člověku s rozumovými schopnostmi a dovodili, že každý člověk bez ohledu na své rozumové schopnosti musí být považován za osobu. ${ }^{71}$ Zákoník na každého jednotlivce nazíral jako na subjekt soukromoprávních vztahů a odsouval dřívější hledisko vycházející z postavení (statusu) konkrétního subjektu. ABGB tak byl zákoníkem, který ustanovil občanskou rovnost před zákonem a zcela otevřeně ji proklamoval. ${ }^{72}$ Historický význam toho ustanovení o to více vynikne, když si uvědomíme, že ve Spojených státech amerických bylo otroctví zrušeno až v roce $1865 .{ }^{73}$

Autoři jediného česky psaného prvorepublikového komentáře k ABGB uvádí, že $§ 16$ je výrazem lidské svobody jako nejvyššího a přirozeného práva lidského. V souladu s Kantovým učením je člověk normotvorným orgánem, tedy sám si určuje prostředky a účel svého jednání. Ve spojení s $§ 7$ ABGB je $§ 16$ výrazem zásady o dovolenosti jednání, která nebyla v právním řádu zvlášt’ upravena ( $\mathrm{v}$ moderním pojetí se odráží v ústavním principu legální licence).$^{74}$ Ze zmíněných ustanovení se odvozovala další tzv. základní lidská práva jako svoboda duševních projevů, právo na tělesnou integritu, občanskou čest, osobní tajemství a také práva statusová. Z $\S 16$ ABGB se rovněž vyvozovala nemožnost člověka omezit

70 SELTENREICH, R. Pojem rekodifikace a vznik soukromoprávních kodifikací v Evropě 19. století. In: DVOŘÁK, J. (ed.). Pocta Sentě Radvanové k 80. narozeninám. Praha: ASPI - Wolters Kluwer, 2009, S. 461.

71 ANDRES - HARTMANN - ROUČEK - SEDLÁČEK, Komentář k československému obecnému zákoníku občanskému a občanské právo platné na Slovensku a v Podkarpatské Rusi. Díl 1, (\$\$ 1 až 284), s. 182.

72 URFUS, V. Historické základy novodobého práva soukromého: Řimskoprávní dédictví a soukromé právo kontinentálni Evropy. 2. vydání. Praha: C. H. Beck, 2001, s. 106.

73 BYDLINSKI, Die „Person“ im Recht, s. 82.

74 ANDRES - HARTMANN - ROUČEK - SEDLÁČEK, Komentář k československému obecnému zákoníku občanskému a občanské právo platné na Slovensku a v Podkarpatské Rusi. Díl 1, (\$§ 1 až 284), s. 184-186. 
svou způsobilost k právním jednáním, jakož i nemožnost vzdát se své svobody. ${ }^{75} \S 16$ sloužil především jako aplikační směrnice stanovující soudci povinnost ve svém rozhodování dbát na to, ,aby důstojnost lidská dotčena nebyla“".76

Na druhou stranu ale nelze význam $§ 16$ v době přijetí zákoníku přeceňovat. Významný rakouský civilista Franz Bydlinski se sice domníval, že se rakouský zákoník ,plně odpoutal od stavovského myšlení a vytvořil koncepci obecné právní způsobilosti“", ${ }^{77} \mathrm{~s}$ takto jednoznačným výkladem ale nesouhlasil německý právník Ulrich von Lübtow, který poukazoval na problematiku nabývání práv podle ABGB. § 18 zákoníku stanovil, že „každý je způsobilý nabývati práv za podmínek ustanovených zákony“ a právě na základě tohoto ustanovení bylo možné způsob nabývání práv diferenciovat podle různých kritérií. Roli hrálo pohlaví, věk, náboženské vyznání, ale i příslušnost ke stavu. ${ }^{78}$ Přestože tedy obecný zákoník občanský formálně zakotvil rovnost všech lidí, určitá práva mohly na základě zvláštních předpisů nabývat pouze některé skupiny obyvatel. Lübtowův pohled tedy podle mého názoru více odpovídá realitě. Disproporce v pojetí osoby v právním smyslu byly odstraněny až pozdějším vývojem.

Ulrich von Lübtow a Franz Bydlinski se nicméně shodují v tom, že pozdější kodifikace (např. švýcarský občanský zákoník ZGB nebo německý občanský zákoník BGB) již pracují s rovnocennou právní subjektivitou každého individua jako se samozrejmostí. Ulrich von Lübtow dochází k závěru, že ,vymezení právní subjektivity člověka není bezobsažným obecným pojmem, nýbrž zásadní právní normou, která pozitivně stanoví, že každý člověk má a musí mít možnost nabývat subjektivní práva. Zároveň tato norma zapovídá, aby byl kdokoliv považován za bezprávného, a neuznává otroctví. Nikdo nesmí být ponížen k pouhému objektu práva, stejně tak jako k pouhému objektu ochrany právního řádu bez subjektivních práv“، ${ }^{79}$

Nezanedbatelný interpretační význam měl také § 17 ABGB, který stanovil, že „,co je přiměřeno vrozeným přirozeným právům, o tom se má potud za to, že tu jest, pokud se neprokáže zákonné omezení těchto práv“. Toto ustanovení upravuje důkazní břemeno v př́ípadě sporu o vrozená (přirozená) práva. Podle autorů zákoníku jsou přirozená práva poznatelná samotným rozumem náležitě vzdělaného člověka a není třeba je zákonem výslovně prohlašovat. Redaktoři tímto ustanovením umně zahalili v absolutistické monarchii nepředstavitelný princip soudcovské nezávislosti (resp. princip iura novit curia-soud zná právo) do hávu přirozených lidských práv. Druhá část $§ 17$ se zdá být v rozporu s výše uvedeným, protože před práva znalým soudcem není potřeba prokazovat zákonné omezení přirozených práv. Už samotný Franz von Zeiller toto ustanovení vykládal tak, že není potřeba dokazovat obsah zákonných norem, ale je nutné prokázat některé skutečnosti, se kterými zákon spojuje určitá omezení práv (např. skutečnost, že je nějaká osoba otcem, nebo že nějaké osobě náleží určitá privilegia apod.). ${ }^{80}$

75

76

77

78

79

80

LAVICKÝ, Občanský zákoník I. Obecná část (\$ 1-654). Komentář, s. 150.

ANDRES - HARTMANN - ROUČEK - SEDLÁČEK, Komentář k československému obecnému zákoníku občanskému a občanské právo platné na Slovensku a v Podkarpatské Rusi. Díl 1, (\$\$ 1 až 284), s. 184-186. BERAN, Pojem osoby v právu, s. 37.

Tamtéž.

Tamtéž, s. 37-38.

ANDRES - HARTMANN - ROUČEK - SEDLÁČEK, Komentář k československému obecnému zákoníku občanskému a občanské právo platné na Slovensku a v Podkarpatské Rusi. Díl 1, (\$\$ 1 až 284), s. 190-191. 
Jak jsem již uvedl výše, další vývoj v rakouské právní doktríně se vyznačoval střetem Kantovy a Hegelovy filozofie. Rakouská právní doktrína v druhé polovině 19. století na rozdíl od Zeillera a první generace komentátorů zákoníku vnímala osobu spíše z pohledu Hegela. Tento pohled upozad'uje Kantův individualismus a pojem osoba vykládá jako výsledek procesu probíhajícího v rámci souboru společenských vztahů, jichž se osoba účastní. Autonomie jednajících subjektů nemůže mít apriorní povahu, individualizace je totiž proces probíhající současně se socializací.

Další konflikt probíhal mezi stoupenci přirozenoprávního a právně pozitivistického pohledu na pojetí osoby v právním smyslu. V prvorepublikové doktríně sice přetrvalo přirozenoprávní nahlížení na člověka, to ale bylo do jisté míry ovlivněno brněnským normativismem, ke kterému se přiklonili také autoři jediného českého komentáře k ABGB. ${ }^{81}$

Jaromír Sedláček k problematice osob v právním smyslu uvádí, že „člověk je přirozenou osobou, poněvadž jde o individualitu, která je nám dána ,přirozeně ‘, což ve vědě znamená, že je nám dána s hlediska př́rodní vědy, t. j. biologie“". Dále rríká, že se přirozená osoba nerovná pojmu člověk, protože člověk je osobou jen potud, pokud je právně relevantní. Ve shodě s předchozím výkladem uzavírá, že v pojmu osoby shrnujeme v jedno všechny právně relevantní lidské vlastnosti a činíme z nich ,individualitu danou pod aspektem právních norem“. 82

Ve výše zmíněném komentáři k ABGB pak Jaromír Sedláček doplňuje své teze konstatováním, že každý člověk je bez ohledu na své rozumové schopnosti považován za osobu. Pojem osoby se vztahuje na všechny lidské bytosti, a to i v př́ípadě, že nejsou schopny právně jednat. V takovém případě za ně vưli projevují jiní, právním předpisem stanovení lidé (zástupci). ${ }^{83}$ Jak jsem již uvedl, v tomto komentáři k obecnému zákoníku občanskému je velmi patrný vliv brněnského normativismu, kdy Jaromír Sedláček v dalším výkladu o osobách vychází právě z této právní teorie. Problematika osoby je vnímána spíše jako personifikace právní normy, přičemž každý normotvorný orgán se považuje za osobu. V normě je stanovena povinnost a tento subjekt povinnosti nazývá osobou. ${ }^{84}$

Prvorepublikoví právní teoretici brali jako samožrejmou skutečnost, že pozitivní právo rozlišuje osobu fyzickou a právnickou. ${ }^{85}$ Přestože se právně-teoretické zdůvodnění pojmu právnická osoba od poloviny 19. století zdánlivě ustálilo, nadále přetrvávaly určitě diskrepance zejména $\mathrm{v}$ otázce, které všechny entity jsou právnickými osobami. Kupř́kladu Emanuel Tilsch uvádí, že ,právo objektivní spojuje oprávnění a závazky nejen s jednotlivým člověkem, nýbrž zná i jiné útvary, jež mohou býti podměty právními. Podmět právní, jenž jest uznán právem objektivním a jenž je rozdílný od jednotlivého člověka (osoby fysické čili prrirozené) nazýváme osobou právnickou“. ${ }^{86}$ Emanuel Tilsch rozlišoval pouze

81 Tamtéž, s. 181-182.

82 SEDLÁČEK, Občanské právo československé. V̌̌eobecné nauky, s. 143.

83 ANDRES - HARTMANN - ROUČEK - SEDLÁČEK, Komentář k československému obecnému zákoníku občanskému a občanské právo platné na Slovensku a v Podkarpatské Rusi. Díl 1, (\$§ 1 až 284), s. 182.

84 LAVICKÝ, Občanský zákoník I. Obecná část (\$ 1-654). Komentářr, s. 135.

85 Srov. ANDRES - HARTMANN - ROUČEK - SEDLÁČEK, Komentár k československému obecnému zákoníku občanskému a občanské právo platné na Slovensku a v Podkarpatské Rusi. Díl 1, (\$§ 1 až 284), s. 249-262, a SEDLÁČEK, Občanské právo československé. V̌̌eobecné nauky, s. 168-184.

86 TILSCH, E. Občanské právo. Část všeobecná. Praha: Wolters Kluwer ČR, 2012, s. 129 
dva typy právnických osob - korporace (spolky) a nadace (fondy). Společnost za samostatnou osobu nepovažoval. ${ }^{87}$

Jiní právníci mezi právnické osoby vůbec neřadili obchodní společnosti (Thöll, Handelsrecht), další připouštěli právní subjektivitu akciových společností (Randa), Wenig naopak všechny obchodní společnosti za právnické osoby považoval. ${ }^{88}$ Sedláček mezi právnické osoby řadil především korporace, nadace, ústavy, a s určitými výhradami i výdělkové společnosti, což rozhodně nepovažuji za koncepční přístup. K této problematice Jaromír Sedláček uvedl, že „,při výkladech o právnických osobách nemůžeme se omeziti jen na t. zv. korporace a nadace, nýbrž musíme výklady založiti šíře a zahrnouti do nich i společnosti; nebot' podle daných právních předpisů není žádného zásadního rozdílu mezi společností a korporací, pak musíme vedle nadací přihlížeti i k jiným prrípadům omezeného ručení proti třetím osobám, kde jmění, jimž se ručí, je personifikováno“. 89

František Weyr, zakladatel brněnského normativismu, se k problematice osob a právní osobnosti vyjádřil takto: „Pojem právní osobnosti jest takto teoretickým pojmem regulativním a systematickým. Jím zaručuje se především jednotnost určité mnohosti právních norem: všecky normy, pocházející od téhož normotvưrce, nebo všecky normy, zavazující týž povinnostní subjekt, tvoří systematickou jednotku normového souboru či komplexu. Jeho může použíti také praktický normotvưrce, aby ulehčil a usměrnil aplikaci (praktické používání) právního řádu, a to tak, že připouští možnost utvoření řady pevných bodů právních osob - které vystupují ve směsi nespočetných právních vztahů (= jednotlivých konkrétních norem druhotných) jako pevné jednotky. Za takovou jednotku prohlašován bývá především fysický jednotlivec (člověk), vedle něho pak řada právnických osob, jimž prísluši samostatná právní osobnost. "90

Weyr dodává, že běžná právní teorie člověku zpravidla připisuje právní osobnost jako určitou vlastnost, kterou mu propůjčuje právní řád, což vyplývá z přirozenoprávní představy, že právní osobnost jakožto vlastnost biologické jednotky „člověk“ rozumí se sama sebou a nemusí být pozitivním právem zvlášt udělována, nýbrž nanejvýš pouze uznávána. ${ }^{91}$ Weyr tento prrístup odsuzuje, protože jeho nedostatky se zřetelně projeví v konstrukci právnických osob, u kterých absentuje „vrozená“ vlastnost právní osobnosti, která je nejčastěji nahrazována teorií fikce. Podle Weyra je při zkoumání právní osobnosti klíčové to, že je př́slušný subjekt schopen být nositelem práv a povinností. A jako představitel brněnského normativismu přidává další schopnost osob v právním smyslu, a to schopnost normotvornou. I v soukromoprávní oblasti totiž dochází k normotvorbě, byt' sekundární v podobě uzavírání smluv, která předpokládá souhlas všech smluvních stran. ${ }^{92}$

V podobném duchu pracoval s pojmem osoba v právním smyslu rakouský právní teoretik Hans Kelsen, podle kterého je pojem osoby možné chápat pouze jako umělou myšlenkovou pomůcku, pomocný pojem, který si právo vytvořilo za účelem názornějšího podání své látky pod vlivem antropomorfizující a personifikující právní mluvy. Osoba je podle

Tamtéž, s. 130.

ANDRES - HARTMANN - ROUČEK - SEDLÁČEK, Komentář k československému obecnému zákoníku občanskému a občanské právo platné na Slovensku a v Podkarpatské Rusi. Díl 1, (\$\$ 1 až 284), s. 251.

SEDLÁČEK, Občanské právo československé. Všeobecné nauky, s. 173.

WEYR, F. Teorie práva. Praha: Wolters Kluwer, a.s., 2015, s. 115.

Tamtéž, s. 112-113.

Tamtéž, s. 113-115. 
něj pouze personifikující souhrnný název pro souhrn práv a povinností. Fyzické a právnické osoby přitom chápe stejně. Fyzickou osobou podle něj není člověk, fyzickou osobu vnímá jako personifikaci norem upravujících chování člověka. Právnická osoba je naproti tomu personifikace norem upravujících chování určité množiny lidí. Kelsen uzavírá, že osoba je pouhou personifikací určitého komplexu norem a tím personifikací určitého dílu objektivního právního řádu, který tvoří mezi všemi jím založenými právy a povinnostmi organickou jednotu. Právu jedné osoby vždy odpovídá povinnost druhé osoby. ${ }^{93}$

Pro normativisty byl při vymezení pojmu osoba také významný pojem ,„přičitatelnosti““. Osoba je totiž podle nich entita, které přičítáme práva a povinnosti. Při definování osoby tak nemůžeme vycházet z pojmu „osoba“ jako takového, ale musíme se zabývat otázkou, co způsobuje skutečnost, že můžeme nějakou entitu považovat za osobu. Tou skutečností je, že určité entitě „přičítáme“ práva a povinnosti. Není podstatné, zdali ono „cosi“, čemu přičítáme práva a povinnosti, budeme označovat jako „osobu“, „subjekt", „,nositele“, „,bod“, nebo dokonce „kotvu“. Podstatné je, že onomu bodu „přičítáme“ práva a povinnosti. Pojem přičitatelnosti tak má pro pochopení pojmu osoby centrální význam. Být osobou podle platného práva musí znamenat být ,čímsi“, čemu přičítáme práva a povinnosti. Pro pochopení toho, co máme rozumět pod pojmem osoby, nemá z normativního hlediska smysl a priori vycházet z pojmu osoby, nýbrž z toho, co způsobuje, že „něco“ můžeme za osobu považovat. ${ }^{94}$

Vztah mezi normou a osobou popsal prof. Weyr takto: „Zmíněný vztah je představou ryze normativní. Možno jej obecně zváti příčetností neboli přičitatelností. To znamená: ve své vlastnosti povinnostního subjektu jest tento subjekt př́ičetný, t. j. normu lze mu ,přičítati‘, norma pak vzhledem k povinnostnímu subjektu jest přičitatelná. Není-li někdo ,příčetným‘, znamená to, že není vzhledem k té či oné normě povinnostním subjektem; není-li určitá norma ,přičitatelnou', znamená to, že určitý subjekt, který jest snad ,příčetný“ vzhledem k jiné normě, nemá povinnosti vzhledem k této určité normě. "95 Příčetnost přitom musí být stanovena normou, přičemž není nutné, aby byla obsažena ve stejné normě, která obsahuje skutkovou podstatu povinnosti. Jen dodám, že příčetnost je nutné v tomto př́padě chápat jako synonymum přičitatelnosti.

Jak je vidno, myšlenky brněnských normativistů mohou být inspirativní i pro současnou právní vědu, která tápe při snaze uchopit kupř́ikladu téma umělé inteligence a robotiky. Pokud při definici osoby nebudeme vycházet z pojmu „osoba“, ale zaměříme se na zkoumání entit, kterým přičítáme práva a povinnosti, nemusíme se alespoň v prvopočátku zabývat svobodnou vůlí, svéprávností, inteligencí či dokonce smrtelností těchto subjektů. Jediným relevantním faktorem je, že ,čemusi“ přičítáme práva a povinnosti.

Vrátíme-li se k problematice fyzických a právnických osob, obecně lze konstatovat, že se posledních dvě stě let koncept těchto entit neustále sbližoval a vývoj doktríny směřuje ke sjednocení právní výbavy (právního statusu) osoby fyzické i právnické. Osoba v právním smyslu představovala v období první republiky, podobně jako dnes, modelovou právní charakteristiku společnou pro soubor lidských bytostí a $\mathrm{k}$ nim se řadící soubor různých útvarů, jimž právo přiznává postavení, resp. právní status, který je v nejobecnějším pohle-

93 KELSEN, H. Ryzi nauka právní. Metoda a základni pojmy. Praha: Orbis, 1933, s. 29-30.

94 BERAN, K. Osoba jako „bod přičitatelnosti“. Právník, 2017, 156, 6, s. 501-522.

$95 \quad$ WEYR, Teorie práva, s. 36. 
du společný pro všechny osoby v právním smyslu a který umožňuje jejich začlenění do souboru právních vztahů v postavení jejich subjektů. Osoba v právním smyslu je tedy nositelem právního statusu, který z ní činí způsobilý subjekt právních vztahů, tedy nositele subjektivních práv a subjektivních povinností z těchto vztahů vyplývajících. ${ }^{96}$

Již samotní autoři obecného zákoníku občanského, vycházejíce z principů přirozeného práva, považovali každého člověka za osobu, tedy za subjekt soukromoprávních vztahů. Inspirováni myšlenkami Immanuela Kanta se tak odpoutali od předchozího pohledu na člověka determinovaného jeho statusem. Zákoník však v tomto nebyl zcela důsledný, protože např. § 18 ABGB stanovil, že každý je způsobilý nabývat práv za podmínek stanovených zákony. Na základě tohoto ustanovení bylo nadále možné způsob nabývání práv diferencovat podle pohlaví, věku, náboženského vyznání nebo příslušnosti ke stavu. Přestože tedy zákoník v $§ 16$ formálně zakotvil rovnost všech lidí, určitá práva mohly na základě zvláštních předpisů nabývat pouze některé skupiny obyvatel. Tento nežádoucí stav byl odstraněn až pozdějším doktrinálním vývojem. I tak je ale nutné zákoníkem zdůrazněný základní princip rovnosti ocenit, nebot' poskytl velkou míru výkladové flexibility, o kterou se mohlo opřít několik generací komentátorů. S nadsázkou lze říci, že bez $\S 16$ by zákoník stěží přežil do dnešních dnů.

\section{Právní úprava fyzických osob v občanském zákoníku z roku 2012}

Předtím, než se budu zabývat právním postavením osob v aktuálně platném občanském zákoníku, považuji za nutné zmínit se o současných teoriích osob v právním smyslu a také o tom, jak na osobu pohlíží soudobá česká právní doktrína.

\subsection{Recentní teorie osob v právním smyslu}

Ve výkladu o současném vývoji pojmu osoba v právním smyslu nemůžeme pominout myšlenky významného rakouského právníka Rolfa Ostheima (1925-2018). Ten se v 70. letech při definování osoby v právním smyslu vrátil ke kořenům práva jako takového, které definuje jako donucovací systém. Předmětem státního donucení pak může být pouze lidské jednání, které je především jednáním volním směřujícím k dosažení určitých cílů. Motivem pro dosažení cílů je uspokojování zájmů nebo potřeb člověka. Rolf Ostheim k tomu ř́íá: „Pokud jsme právo chápali jako řád nadaný donucovací mocí, který reguluje vnější lidské chování, pak můžeme z hlediska motivace tohoto chování chápat právo jako řád, který se vztahuje ke sledování lidských zájmů, který je nadán donucovací mocí،“97 Právní řád rozlišuje zájmy žádoucí, resp. přikázané, a zájmy nežádoucí, tedy zakázané. Mezi tím existuje velká množina zájmů, které nejsou přikázané, ani zakázané, a jednání směřující k jejich naplnění bude jednáním dovoleným.

Podle Rolfa Ostheima zájem a vůle tvoří ,jjediný správný bod přičitatelnosti, k němuž se vztahuje právní osobnost““ ${ }^{98} \mathrm{~V}$ momentě, kdy stát hledí na zájmy všech podřízených osob stejně, nahlížíme na tyto osoby jako na subjekty práva. Na historickém příkladu otroků Rolf Ostheim popisuje, že samotná vůle subjektu nepostačuje k přiznání právní

\footnotetext{
96 LAVICKÝ, Občanský zákoník I. Obecná část (\$ 1-654). Komentářr, s. 136.

97 OSTHEIM, Zur Rechtsfähigkeit von Verbänden im österreichischen bürgerlichen Recht, s. 4.

98 BERAN, Pojem osoby v právu, s. 113.
} 
subjektivity. Otroci měli bezesporu vůli, ale státní moc nepřiznávala jejich zájmům právní ochranu, a tudíž ani nebyli považováni za osobu v právním smyslu.

Rolf Ostheim dále uvádí, že každá osoba v právním smyslu má dva atributy, a to právní způsobilost a způsobilost k právnímu jednání. Právní způsobilostí se rozumí možnost nabývat práva a povinnosti, pokud nastanou právem předvídané okolnosti. Díky této možnosti mohou osoby vytvářet právní vztahy za účelem dosažení svých zájmů. Způsobilost k právnímu jednání pak představuje vůli, díky které osoba do právních vztahů vstupuje. Způsobilost k právnímu jednání úzce souvisí s právní způsobilostí, protože pouhá schopnost nabývat práva a povinnosti bez možnosti právně jednat je sama o sobě bezúčelná. U právnických osob je proto nezbytná existence orgánů, které za ni projevují vůli.

Rolf Ostheim k tomu ř́ká, že „,každá zájmová jednotka, která byla uznána jako podklad pro osobu (personifikaci), se musí vyznačovat organizací, která ji alespoň potenciálně umožní vstupovat do jí přiznaných práv a povinností“. Jako zájmovou jednotku Rolf Ostheim označoval i člověka, a proto právní doktrínu obohatil o následující definici osoby v právním smyslu: „Osoba je z hlediska možnosti mít práva a povinnosti organizovaná zájmová jednotka, která je uznána právním řádem tím, že je jí propůjčena způsobilost k právním jednáním (právní subjektivita) a je tak potenciálně způsobilá k samostatné účasti na právních vztazích." 99

Další významnou osobností zabývající se pojmem osoba byl německý právník Fritz Rittner (1921-2010). Ten zdůrazňuje, že by pojem osoby neměl vést k dojmu, že si jsou fyzické a právnické osoby podobné. Právnická osoba se svou strukturou od fyzické osoby odlišuje. Právnická osoba není sociálním útvarem, ale je zcela výtvorem (produktem) práva. Naproti tomu člověk není svou podstatou osobou (právním subjektem), právo mu právní subjektivitu propůjčuje. Fyzické osoby, které právnickou osobu tvoří, se nikdy nestávají její součástí. Jejich účast na právnické osobě nic nemění na jejich podstatě. Fritz Rittner také odmítá úplnou rovnoprávnost fyzických a právnických osob, podle něj mohou právní předpisy „obsah“ právní způsobilosti právnických osob libovolně měnit. 100

Fritz Rittner dále uvádí, že u každé normy dopadající na právnické osoby je nutné zkoumat, jakým způsobem ji lze aplikovat. Právnické osoby představují velmi heterogenní skupinu subjektů, a tak je vždy nutné seznat jejich strukturu a aplikaci normy této skutečnosti přizpůsobit. Tím se zásadně odlišují od fyzických osob, v jejichž případě by na ně dopadající právní normy měly být aplikovány podle principů rovnosti. ${ }^{101}$

Naproti tomu další německý právník Thomas Raiser (nar. 1935) ř́ká, že obsah pojmů fyzické a právnické osoby je stejný, protože pouze absolutní právní rovnost obou osob zaručuje účast právnické osoby v právním životě. Právnická osoba má stejně jako osoba fyzická jméno (název), je způsobilá nabýt jakýchkoliv majetkových práv (včetně dědictví), má právo na ochranu osobnosti, být členem jiných právnických osob apod. Právnické osoby jsou analogicky k fyzickým osobám také subjektem právních povinností. Thomas Raiser uvádí, že ,„práva a povinnosti, závazková, majetková a členská způsobilost, stejně jako ručení vlastním majetkem jsou součástí koncepce pojmu právní způsobilosti, a proto patří i k pojmu právnických osob. Právnické osoby musí mít také stejný př́istup k právní

\footnotetext{
99 OSTHEIM, Zur Rechtsfähigkeit von Verbänden im österreichischen bürgerlichen Recht, s. 38.

100 BERAN, Pojem osoby v právu, s. 114-118.

101 Tamtéž, s. 114-118.
} 
ochraně poskytované státem jako fyzické osoby“. ${ }^{102}$ Thomas Raiser své úvahy uzavírá konstatováním, že právní řád by měl pojem právnické osoby vymezit tak, aby byl obsah právní způsobilosti právnických osob totožný s obsahem právní způsobilosti osob fyzických: „Proto musí být právnické osoby definovány jako spolky a organizace, které v sociálním životě vystupují a jednají jako nezávislé subjekty, které právo uznává stejně jako fyzické osoby a přiznává jim v principu neomezenou právní způsobilost.“103

Rakouský právník Franz Bydlinski (1931-2011) se zabýval vývojem pojmu osoba z pohledu postmodernismu, tedy jednoho z nejvýznamnějších současných filozofických směrů, ${ }^{104}$ a konstatuje, že současné platné právo zcela vychází z přirozenoprávních (racionalistických) koncepcí osoby z 19. století a postmodernismus se v této otázce do platného práva promítá pouze minimálně. ${ }^{105}$

Přestože můžeme souhlasit s tezí, že se postmodernismus bezprostředně neprojevuje v právní úpravě osob, postmodernistické pojetí světa má podle mého názoru na chápání pojmu osoby nezanedbatelný vliv, byt' se současní filozofové staví k postmodernismu rezervovaněji než na přelomu tisíciletí. Postmodernismus zpochybňuje schopnost lidského myšlení odrážet realitu vnějšího světa a úlohu jazyka jako prostředku a produktu myšlení sloužícího k formulování a zprostředkování těchto poznatků jiným osobám. Podle postmodernistů je pravda nepoznatelná, veškeré poznání je historicky a kulturně podmíněné, neúplné a relativní. Hodnoty nejsou odrazem objektivní reality a objektivních zákonitostí, ale projevem vůle jednotlivých subjektů. ${ }^{106}$

Postmodernismus odmítá pojetí osoby, které se vyvíjelo v linii antika - křest’anství osvícenství - novodobé společenské vědy, a vytváří zcela nové paradigma. Jak uvádí Martin Škop, zajímavým fenoménem postmoderního uvažování je „,rozkolísání pojmu subjekt“. ${ }^{107}$ Dosavadní pojetí pojmu osoba zdůrazňovalo člověka a jeho vlastnosti, resp. atributy odvozené od lidského jedince. Postmodernismus naproti tomu orientuje pojem osoba na účelovost. Subjekt v právním smyslu totiž z pohledu postmodernismu nezahrnuje pouze člověka, ale jakoukoli entitu, o které právo rozhodne, že je z pohledu práva subjekt. ${ }^{108}$ Někteří právní teoretici dokonce přichází s tezí, že čím dál více věcí bude nutné považovat za subjekt, nikoliv jen za objekt práva (např. zvířata nebo životní prostředí, o jejichž záležitosti by pečoval poručník). Objevila se např́iklad iniciativa, aby řeka Whanganui na Novém Zélandu nebo některé řeky v Indii měly přiznána některá práva typická pro osoby. ${ }^{109}$

Postmodernistický přístup $\mathrm{k}$ této problematice zdůrazňuje, že o přiznání právní subjektivity rozhoduje zákonodárce a toto rozhodnutí tedy není politicky neutrální. Z toho vyplývá, že určení, co je, a co naopak není právním subjektem, je problémem politiky. Podle Jana Hurdíka postmodernismus odmítá dlouhým historickým vývojem vybudované

102 RAISER, Der Begriff der juristischen Person. Eine Neubesinnung, s. 130.

103 Tamtéž.

104 HURDÍK, Pojem osoba a geneze jeho obsahu jako základ konstrukce osob v právním smyslu, s. 312.

105 BERAN, Pojem osoby v právu, s. 131-132.

106 HURDÍK, Pojem osoba a geneze jeho obsahu jako základ konstrukce osob v právním smyslu, s. 312.

107 ŠKOP, M. Právo v postmoderni situaci. Brno: Masarykova univerzita, 2008, s. 89.

108 Tamtéž.

109 HUTCHINSON, A. The Whanganui River as a Legal Person. Alternative Law Journal, 2014, XXXIX, 3 , s. $179-182$. 
pojetí člověka založené na myslící rozumové nezávislé substanci. „Subjekt je tak souborem názorů, projevovaných citů a vůle, kterým chybí jakýkoliv společný princip. Jediný cíl a jeho existence jsou přijímány pouze v rámci dané společnosti, jako součást společenských vztahů. Jednotlivce je možno chápat pouze jako prvek těchto vztahů."110

Co je nepochybné, postmodernismus svým akcentem na pragmatičnost lidského chování vede k rozvolňování vazby pojmu osoba na atributy odvozené od člověka a otvírá prostor pro formulaci tohoto pojmu ryze účelově, což v konečném důsledku vede ke sbližování právního modelu fyzické a právnické osoby (resp. jejich právní výbavy), které ostatně probíhá posledních 200 let. Fyzické osoby však i nadále zůstávají jakousi privilegovanou kategorií - mají aktivní a pasivní volební právo, mohou se stát členy politických stran nebo církví, jsou subjektem základních lidských práv, např́íklad práva na život, na soukromí, svobody slova, práva na vzdělání atp. Fyzické osoby mohou vstupovat do manželského svazku, mohou založit rodinu, mít potomky, kteří se narozením automaticky stávají osobou v právním smyslu. Na druhé straně mohou být fyzické osoby odsouzeny k trestu odnětí svobody. To vše si lze u právnických osob těžko představit.

Význam pojmu osoba posunují také informační technologie. Kyberprostor totiž v souvislosti s vývojem umělé inteligence vyžaduje vlastní chápání subjektu a podle některých autorů bude v budoucnu nutné přiznat subjektivitu umělým bytostem. Na otázku, jestli by měl mít i kyberprostor práva a povinnosti odpovídá Martin Škop nejednoznačně: „Může to být určitý aspekt člověka a jeho rysů, pouze transformovaný do jiného prostředí... Práva a povinnosti si i zde zachovávají své podstatné součásti.“111 Nicméně dodává, že ,jiné prostředí v tomto pojetí vyžaduje jiný subjekt". ${ }^{112}$

I nahlížení na samotnou fyzickou osobu se ale postupem času mění. Díky biotechnologiím může být embryo biologických rodičů vloženo do dělohy náhradní matky. Náhradní matka odnosí plod a porodí dítě pro biologické rodiče. Je dokonce možné, aby takové embryo vzniklo spojením DNA 3 různých jedinců. ${ }^{113}$ Diskutována je také problematika tzv. biotechnologických humanoidů, tedy bytostí, které by mohly vzniknout genovou manipulací nebo použitím umělých orgánů apod. Bude možné bytost, která bude např́iklad ze 3/4 složena z uměle vytvořených orgánů považovat za fyzickou osobu? I na tyto výzvy bude muset zákonodárce $\mathrm{v}$ budoucnu nějakým způsobem reagovat.

V závěru této podkapitoly můžeme konstatovat, že při definování osob vycházely právní řády západních demokratických států ve 20. století z osvícenských a přirozenoprávních principů formulovaných zhruba od poloviny století osmnáctého. Obraz člověka v právním řádu je obrazem jedinečného, na sebe odkázaného individua, které sice také žije v sociálních a dalších společenských vztazích, jako takové je ale vůči těmto vztahům primární. Základní jednotkou právního řádu je podle přirozeného práva jedinečné, svobodné, na sebe odkázané individuum, tj. právní subjekt. Není to ani rodina, domácnost nebo nějaké jiné lidské společenství, jak bylo podle dřívějších koncepcí běžné.

\footnotetext{
110 HURDÍK, Pojem osoba a geneze jeho obsahu jako základ konstrukce osob v právním smyslu, s. 312.

111 ŠKOP, Právo v postmoderní situaci, s. 99.

112 Tamtéž.

113 Exclusive: World's first baby born with new "3 parent” technique. New Scientist. [online]. Dostupné na: https://www.newscientist.com/article/2107219-exclusive-worlds-first-baby-born-with-new-3-parent -technique/\#ixzz67WGMzEgv. [cit. 08. 12. 2019].
} 
Do dnešního právního řádu nevstupuje člověk se svým metafyzickým a transcendentálním určením. Vstupuje do něj jako individuum obdařené svobodou volit si své určení samo. To se projevuje např́klad v obsahu základních občanských a lidských práv a svobod - ve svobodě náboženského vyznání, svobodě pohybu, svobodě projevu, v právu vlastnit majetek apod. Nejde o metafyzickou svobodu, ale o subjektivní svobodu jednotlivce ve smyslu svobodné volby a svobodného sebeurčení.

Stát přitom nevystupuje jako entita, která by naplňování obsahu individuálních práv a svobod vynucovala. Stát vystupuje v roli garanta zajišstujícího právě svobodu volby každého právního subjektu. Tento princip vyjadřuje například článek 1 Listiny základních práv a svobod, podle kterého jsou lidé „,svobodní a rovní v důstojnosti i v právech. Základní práva a svobody jsou nezadatelné, nezcizitelné, nepromlčitelné a nezrušitelné“. Role státu, jakožto subjektu, který chrání práva a svobody občanů, je zdůrazněna v článku 36 odst. 1 Listiny: „Každý se může domáhat stanoveným postupem svého práva u nezávislého a nestranného soudu a ve stanovených př́ípadech u jiného orgánu.“

Od druhé poloviny minulého století ale v západních demokratických právních řádech pozorujeme čím dál zřetelnější trend, kdy se právní předpisy netýkají osob jako takových, ale upravují jejich role a funkce. Nejvíce je tento trend patrný např́iklad v právu sociálního zabezpečení, pracovním právu nebo v normách regulujících podnikání, ale pozorovatelný je i v jiných oblastech práva. Právní předpisy se v těchto př́padech týkají osob jen v určitých funkcích - tj. např́iklad v situaci, kdy řídí dopravní prostředek, při hledání zaměstnání, při vzdělávání, při podnikatelské činnosti apod. V těchto př́ípadech se osoba jeví jen jako př́ípad, jenž je určen stanovenými věcnými předpoklady a s nímž se pak nakládá podle konkrétní právní úpravy. Z osob se tak stává jen jakýsi předmět regulace, osoba jako taková je opomíjena a přirozeným právem formulovaná svoboda „volit si své určení sám“ je stále více omezována. Tento trend, kdy jsou regulovány další a další aspekty života lidí, navíc v posledních desetiletích stále zrychluje a zesiluje.

\subsection{Osoba v právním smyslu z pohledu současné české právní doktríny}

Významný český právní teoretik Jiří Boguszak rozumí pod „subjekty práva osoby v právním slova smyslu, tj. osoby, které mají právní subjektivitu“. 114 Právní subjektivitou označuje způsobilost k právům a povinnostem, tedy způsobilost být subjektem práva. V souvislosti s tím kritizoval občanský zákoník z roku 1964, který obsahoval rubriku druhé hlavy ve znění „Účastníci občanskoprávních vztahư“, a to z toho důvodu, že právní subjektivitu lze chápat pouze jako možnost (způsobilost) stát se účastníkem právního vztahu a neznamená tedy automatickou účast v takovém právním vztahu. Existence právní subjektivity je nezávislá na existenci právních vztahů, kupř́ikladu způsobilost k vlastnickému právu neznačí vlastnictví kterékoli věci. Subjekt práva je subjektem svobodným, který ze své vůle může, ale zároveň nemusí do právních vztahů vstupovat. ${ }^{115}$ Pojem ,účastník“ ostatně občanský zákoník z roku 1964 používal na mnoha místech, nebot’ se vyhýbal pojmu „osoba“. Původní koncepce socialistického zákoníku nevycházela z tradiční bipartice fyzických a právnických osob, ale používala termíny „občan“ a „socialistická organizace“,

114 BOGUSZAK, J. - ČAPEK, J. - GERLOCH, A. Teorie práva. 2., přeprac. vyd. Praha: ASPI, 2004, s. 135.

115 Tamtéž, s. 135. 
pojem „účastník“ byl těmto dvěma pojmům nadřazený. ${ }^{116}$ Ani četné novelizace zákoníku neodstranily tuto zásadní terminologickou vadu, to se povedlo (byt’ ne úplně dokonale) až v občanském zákoníku z roku 2012.

Jaromír Harvánek podobně jako Rolf Ostheim za subjekty práva označuje ty osoby, o kterých to právní normy stanoví. Subjekty práva pak dělí na jednotlivce (fyzické osoby) a organizace (právnické osoby), které sdružují jednotlivce sledující určitý společný hospodářský nebo jiný cíl. Jaromír Harvánek dále rozlišuje pasivní stránku právní subjektivity, kterou se rozumí způsobilost $\mathrm{k}$ právům a povinnostem, resp. právo být subjektem práv a povinností, a aktivní stránku subjektivity ve smyslu způsobilosti k právním úkonům (svéprávnosti), tedy způsobilosti právně jednat. ${ }^{117}$

Do teorie subjektů přináší odlišný pohled Viktor Knapp, který rozlišuje dva subjekty právních norem - právotvorný subjekt a subjekt, kterému je právo určeno (tedy adresáta právních norem). Právotvorným subjektem je ve většině zemí světa stát. Právotvorný subjekt je oprávněn vytvářet právní normy, na základě kterých vznikají právní povinnosti obecně vymezenému okruhu subjektů, případně i individuálně určeným subjektům (např. pokud je stát stranou soukromoprávní smlouvy). Adresáty právní normy jsou subjekty, jimž jsou adresovány př́kazy, zákazy, resp. kterým jsou právní normou dána určitá dovolení (modality normativnosti). Zákonodárce určuje, kdo je adresátem právních norem, a tím také vymezuje právní subjektivitu těchto entit. Adresátem právních norem nejsou jen fyzické osoby, ale také sdružení osob nebo účelová sdružení majetku, čímž právo vytváří fikci právní osobnosti těchto subjektů, které označujeme jako právnické osoby. Hlavní rozdíl mezi právotvorným subjektem a adresáty právních norem je podle Viktora Knappa ten, že adresát právní normy je oprávněn stanovit povinnost pouze individuálně určeným subjektům (např. na základě smlouvy). ${ }^{118}$

Viktor Knapp dále uvádí, že se člověk „,V určitém právním řádu nestává fyzickou osobou, tj. subjektem práva tím a proto, že se narodil, ale tím a proto, že od narození, popř. už před ním, se jeho osobní status spravuje nějakým právním řádem“. ${ }^{119}$ Právní subjektivita není apriorní, ale vyplývá z právního řádu, z úmyslu zákonodárce. Tento princip je nejzřetelnější u právnických osob, nebot' ty podle Viktora Knappa nemají žádná přirozená práva. Zákonodárce je při vymezení obsahu právní subjektivity zejména $\mathrm{v}$ př́ípadě fyzických osob limitován přirozenoprávními východisky, která musí respektovat a nemůže si tudíž počínat svévolně.

Karel Beran naproti tomu klade důraz na rozlišování soukromoprávní a veřejnoprávní subjektivity. Člověk může být nositelem pouze soukromoprávní subjektivity. V prrípadě právnických osob je situace složitější, nebot' ty mohou být nositelem výhradně soukromoprávní subjektivity (tzn. že se mohou samostatně zavazovat a nabývat oprávnění), jiné pak mohou mít soukromoprávní i veřejnoprávní subjektivitu (kromě vstupování do soukromoprávních závazků mají i pravomoc k normotvorbě - např. stát) a konečně existují i právnické osoby, které mají pouze veřejnoprávní subjektivitu (napřr. orgány úruadů). Toto dělení subjektivity odmítá Viktor Knapp, podle kterého má toto rozlišování pouze histo-

116 ŠVESTKA, J. - SPÁČIL, J. - ŠKÁROVÁ, M. - HULMÁK, M. a kol. Občanský zákoník I. § 1 až 459. Komentár̆. 2. vydání. Praha: C. H. Beck, 2009, s. 102.

117 HARVÁNEK, J. Teorie práva. Plzeň: Vydavatelství a nakladatelství Aleš Čeněk, 2008, s. 314.

118 KNAPP, V. Teorie práva. Praha: C. H. Beck, 1995. Beckovy právnické učebnice, s. 70-71.

119 KNAPP, V. O právnických osobách. Právník, 1995, 134, 10-11, s. 982. 
rický význam a nemá logický základ. Doslova uvádí následující: „Pro teorii a praxi práva veřejného, jakož i pro teorii a praxi práva soukromého nemají právnické osoby veřejného práva žádný význam. “120 Viktor Knapp vidí smysl v rozlišování pouze právnických osob soukromého práva a právnických osob soukromého a veřejného práva zároveň. Primární je podle něj subjektivita soukromoprávní a veřejnoprávní subjektivita je „něco navíc““.121

Podobně jako v zahraničí se i česká právní doktrína zabývá spíše teoretickým vymezením právnických osob. Podle Viktora Knappa není právnická osoba apriorním pojmem aplikovaným v právním řádu, ale pojmem vytvořeným právním řádem samým. Této tezi oponuje Karel Beran, který říká, že právní řád může nepochybně stanovit, že je určitý útvar osobou, pokud však taková osoba nebude fakticky schopna být nositelem práv a povinností, je degradována na pouhý „právní subjekt“. Ten, kdo je osobou v právním smyslu, je zároveň právním subjektem, ale právní subjekt nemusí být nutně osobou v právním smyslu. Za osobu lze podle něj považovat pouze ten subjekt práva, který lze identifikovat, který je způsobilý jednat a který za své jednání odpovídá. ${ }^{122}$

Jak vyplývá z výše uvedeného, česká právní doktrína je ovlivněna především Ostheimovým pohledem na teorii osob. Dále je nutné vypíchnout, že většina českých právních teoretiků inklinuje k přirozenoprávním východiskům při popisu této problematiky. Knappova teorie osob je zřetelně ovlivněna juspozitivismem a postmodernismem a jako taková je v českém právním prostředí spíše ojedinělá. Zároveň se sluší poznamenat, že současná česká právní věda na rozdíl od rakouských či německých právních teoretiků výrazným způsobem nepřispívá k rozvoji vnímání pojmu osoba v právním smyslu. Posledním výrazným př́ispěvkem v této oblasti jsou teorie brněnských normativistů popsané výše.

\subsection{Pojem osoba v občanském zákoníku z roku 2012}

Autoři občanského zákoníku z roku 2012 označují (byt' nepřímo) rakouský občanský zákoník za obecný ideový zdroj rekodifikace, ${ }^{123}$ což se bezesporu projevilo také v koncepci osob v právním smyslu. Pojetí osob v aktuálně platném občanském zákoníku je tak přímým dědicem Zeillerova přirozenoprávního myšlení, které bylo inspirováno Kantovým pojetím lidské důstojnosti.

Co se týče samotného textu občanského zákoníku, těžiště právního postavení fyzických osob nalezneme v $§ 19$ ObčZ. Důvodová zpráva k zákoníku uvádí, že pro $§ 19$ ObčZ posloužil jako inspirační zdroj $§ 16$ ABGB, nepřejímá jej však doslovně, protože „doba osvícenského racionalismu, jemuž byl koncept $\S 16$ ABGB podřízen, pominula některá další relevantní hlediska“. ${ }^{124}$ Stejně jako obecný zákoník občanský staví i občanský záko-

120 Tamtéž, s. 997.

121 BERAN, Pojem osoby v právu, s. 148.

122 Tamtéž, s. 162.

123 „Základním obecným ideovým zdrojem rekodifikace je vládní návrh občanského zákoníku bývalého Československa z r. 1937, který nebyl jako zákon přijat kvůli událostem následujícím po mnichovské dohodě. Z koncepčního hlediska má význam, že tento vládní návrh sledoval modernizační revizi rakouského všeobecného zákoníku občanského (ABGB) z r. 1811 v jeho konfrontaci s novějšími evropskými zákoníky, zejména německým a švýcarským. Se zřetelem k tomu je třeba zdůraznit, že se jednalo o návrh myšlenkově soudržný, s jasným filosofickým zázemím převzatým z rakouského zákoníku, koncepčně navazující na tradice středoevropského právního myšlení.“Z Zdroj: Důvodová zpráva k zákonu č. 89/2012 Sb., občanský zákoník, s. 17.

124 Důvodová zpráva k zákonu č. 89/2012 Sb., občanský zákoník, s. 45. 
ník z roku 2012 svou koncepci na jusnaturalistickém hledisku. § 19 ObčZ zní následovně: „(1) Každý člověk má vrozená, již samotným rozumem a citem poznatelná přirozená práva, a tudíž se považuje za osobu. Zákon stanoví jen meze uplatňování přirozených práv člověka a způsob jejich ochrany. (2) Přirozená práva člověka spojená s osobností člověka nelze zcizit a nelze se jich vzdát; stane-li se tak, nepřihlíží se k tomu. Nepřihlíží se ani k omezení těchto práv v míré odporující zákonu, dobrým mravům nebo veřejnému pořádku.“

V porovnání s $§ 16$ ABGB nedeklaruje ObčZ z důvodu neaktuálnosti zákaz otroctví a neobsahuje ani vyvratitelnou právní domněnku přirozených práv obsaženou v $§ 17$ ABGB. Druhý odstavec $§ 19$ ObčZ, který je inspirován švýcarským občanským zákoníkem, totiž deklaruje zdánlivost (viz formulaci „nepřihlíží se“) těch právních jednání, kterými osoba zcizuje svá přirozená práva nebo se jich vzdává či je jinak omezuje v míře odporující zákonu, dobrým mravům nebo veřejnému pořádku. Zdánlivé tak tedy jsou jak tzv. otrocké smlouvy, tak například takový projev vůle, jímž člověk žádá druhého, aby byl usmrcen (eutanázie). ${ }^{125} \S 16$ ObčZ také výslovně deklaruje, že se nikdo ani z části nemůže vzdát právní osobnosti ani svéprávnosti, a pokud tak učiní, nepřihlíží se k tomu (tzn. že je opět stanovena zdánlivost takového jednání). Rakouský zákoník takové ustanovení neobsahoval, ale nemožnost člověka omezit svou způsobilost k právním jednáním, včetně otázky neodvolatelnosti plné moci, jakož i nemožnost vzdát se své svobody s následky neplatnosti u závazků osobního rázu se dovozovala přímo z § 16 ABGB.

Široký výklad § 16 ABGB a jeho význam pro soudní aplikaci práva vyplýval z neexistence ústavních norem v době vzniku zákoníku, které by upravovaly obecné principy právního řádu a základní lidská práva. $\mathrm{V}$ době, kdy jsou obecné právní principy a lidská práva upraveny ústavními předpisy a mezinárodními smlouvami, nemá § 19 ObčZ velký praktický význam, nebot' i ve světle $\S 2$ odst. 1 ObčZ v podstatě pouze dubluje podobná ustanovení v těchto pramenech práva.

Časté diskuse o prvotnosti osoby v právním smyslu vyřešil aktuálně platný občanský zákoník inspirací $\S 16$ ABGB. Sled příčin a účinků v oblasti pojetí člověka jako osoby je následovný: (a) východiskem je existence člověka, (b) který je ze své existence vybaven vrozenými, již samotným rozumem a citem poznatelnými přirozenými právy, (c) což vede k důsledku, že je považován za osobu. Tento proces se děje mimo zákon, který stanoví jen meze uplatňování přirozených práv a způsob jejich ochrany. Člověk je reálným biosociálním základem jeho odrazu v právu (tedy fyzické osoby) a fyzická osoba je souborem předpokládaných, nicméně v realitě existujících či očekávaných vlastností člověka, nezbytných pro vstup člověka do právních vztahů. ${ }^{126}$

Pojetí přirozených práv v občanském zákoníku z roku 2012 je zcela v souladu s předchozím výkladem týkajícím se obecného zákoníku občanského. § 19 ObčZ potvrzuje ústavní princip legální licence, tedy „co není zakázáno, je dovoleno“, podobně jako to činil ABGB v $§ 16$ ve spojení s $§ 7$. Důvodová zpráva zdůrazňuje fakt, uznaný i českým ústavním pořádkem, že přirozená svoboda člověka má přednost před státem v tom smyslu, že stát není tvưrcem svobody člověka, ale jejím ochráncem. ${ }^{127}$

\footnotetext{
125 Tamtéž, s. 45.

126 LAVICKÝ, Občanský zákoník I. Obecná část (\$ 1-654). Komentář, s. 150.

127 Důvodová zpráva k zákonu č. 89/2012 Sb., občanský zákoník, s. 20.
} 
Redaktoři občanského zákoníku dále v důvodové zprávě uvádí, že „návrh § 18 respektuje tradiční dělení osob na osoby fyzické a právnické. Zvolený výraz je konformní terminologii Listiny základních práv a svobod (srov. čl. 1 nebo 42 odst. 3). Protože fyzická osoba je totožná s člověkem, používá osnova synonymicky označení ,člověk‘. Obecné nadužívání pojmu ,fyzická osoba‘ bylo v našem zákonodárství zavedeno po roce 1990 jako nouzová náhražka dosavadního a zcela nevhodného státoprávního ,občan', nedocenilo se však, že se jedná o termín vlastní zejména právu mezinárodního obchodu, zatímco tradiční občanské zákonodárství se tomuto pojmu vyhýbá a používá jej zřídka. (Tuto tradici respektoval ještě občanský zákoník z r. 1950, který o fyzické osobě mluvil pouze na jediném místě.) Občanské zákoníky kontinentálního systému používají jako základní termín přirozená osoba (Německo, Švýcarsko, Nizozemí, Lichtenštejnsko aj.) či fyzická osoba (Itálie, Polsko, Rusko aj.), vždy však velmi střídmě na jednom či dvou místech s tím, že normativní text nejčastěji pracuje se slovy, jako jsou člověk, lidé, dítě, nezletilý, manžel, zůstavitel atd. Osnova sleduje stejnou metodu."128

Z použití spojení „,považuje se za osobu“v $§ 19$ ObčZ a z výše uvedené části důvodové zprávy by se mohlo zdát, že zákonodárce zde zakotvuje fyzickou osobu jako fikci člověka. ${ }^{129}$ Tento závěr by ale zcela popřel několik století dlouhý vývoj právní teorie vymezující obsah pojmu osoba v právním smyslu. Jan Hurdík mi v komentáři k občanskému zákoníku dává za pravdu, když uvádí, že ,zz hlediska obecného vnímání člověka i z hlediska jeho vnímání občanským zákoníkem je člověk biosociální realitou, osoba (fyzická) je souborem rozumových a volních schopností člověka, které právo využivá jako nástroj integrace člověka do svých regulativních sítí'“130

Jak je naznačeno výše v důvodové zprávě, občanský zákoník skutečně používá termín „fyzická osoba“" pouze na deseti místech, naproti tomu ,člověk“ je zmíněn přesně stopadesátkrát. Tento postup považuji za metodologicky nesprávný a rovněž odporující doktrínou vymezenému pojmu „osoba“ v právním smyslu. Rozumím snaze redaktorů odpoutat se od předchozí kodifikace soukromého práva a zdůraznit tak diskontinuitu mezi socialistickým a současným zákoníkem, nicméně v tomto případě se s jejich postupem nemohu ztotožnit. Rakouský občanský zákoník volí přístup přesně opačný a z hlediska právní teorie správnější - o člověku hovoří pouze v $§ 16$, který zdůrazňuje přirozenoprávní východiska zákoníku, a dále jen na dvou dalších místech, všude jinde je použito pojmu „osoba“ v různých modifikacích. Redaktoři ABGB správně vnímali konstrukt fyzické osoby jako redukci multidimenzionální povahy člověka, která je použitelná v právních vztazích. Fyzickou osobu považovali za zjednodušenou transformaci podstaty člověka v abstraktní pojem, se kterým je právo schopno dále nakládat. Pojem osoba je pojmem ryze právním, zatímco člověk existuje v reálném světě. Je otázkou, jestli si autoři občanského zákoníku z roku 2012 byli vědomi těchto teoretických východisek, každopádně do samotného textu kodexu se nepromítla.

Můžeme tedy potvrdit hypotézu vyřčenou v úvodu této studie. Redaktoři občanského zákoníku z roku 2012 se nezaměřili na precizní teoretické vymezení osob v právním smyslu, resp. na odlišení pojmu osoba od pojmu člověk, a nerespektovali tak několik staletí

128 Důvodová zpráva k zákonu č. 89/2012 Sb., občanský zákoník, s. 44-45.

129 Tamtéž, s. 24: „Výrazem ,považuje se za“ nebo ,hledí se na“ se označuje právní fikce.“

130 ŠVESTKA, J. - DVOŘÁK, J. - FIALA, J. Občanský zákoník. Komentár. Svazek I (\$ 1-654). Praha: Wolters Kluwer, a.s., 2014, s. 98. 
trvající vývoj právní doktríny v této oblasti. Naproti tomu pojem osoby byl v ABGB vymezen přesněji a v souladu s tehdejšími poznatky právní vědy.

V současné době zůstává nadále problematické vymezení právnických osob a vzájemného vztahu mezi právnickými a fyzickými osobami. Spor o podstatu právnických osob má závažné koncepční dopady na pojetí práva jako celku, a to z toho důvodu, že postavení osoby v právním smyslu je dominantním prvkem veškeré právní regulace.

Důvodová zpráva k občanskému zákoníku z roku 2012 proti současným trendům uvádí, že ,člověk a právnická osoba principiálně nejsou a nemohou být obecně v rovném právním postavení. Člověk má ze své podstaty nezadatelná přirozená práva. Zákon nelimituje základní práva člověka, nýbrž naopak základní práva člověka představují limit pro zákon (D. Hesselberger). Tak to také vyjadřuje Listina základních práv a svobod a celý český ústavní pořádek. Naproti tomu základ juristického postavení právnických osob je odlišný; z něho také vyplývají jiné právní důsledky. Právnická osoba je umělý organizační útvar vytvořený člověkem a sloužící jeho zájmům. Na rozdíl od člověka, jehož právní osobnost pozitivní právo uznává (uznat musí), právnické osobě její právní osobnost pozitivní právo poskytuje (dát může). Odtud se odvozuje naprosto odlišné právní postavení obou skupin právních subjektů, o jejichž právní rovnosti nelze mluvit ani ve sfére osobních práv, ani v celé sféře práv majetkových. Tato rovnost se uplatňuje, a to ještě nikoli bezvýjimečně, v oblasti práv věcných a obligačních“. 131

Dále je v důvodové zprávě uvedeno následující: „Akcent na zásadu rovnosti jednak zastírá prrirozenou nerovnost mezi fyzickými a právnickými osobami, nebot' mezi nimi nemůže být právně, především v oblasti osobních práv, rovnosti nikdy dosaženo, jednak pomíjí hledisko ochrany slabší strany, která je pro soukromé právo stejně významná jako zásada rovnosti. Preference této zásady totalitním zákonodárstvím, vedla k popření základní funkce občanského zákoníku, k rozbití jednoty soukromého práva a $\mathrm{k}$ ideologickému popření jeho existence." 132

A dále: „Pokud se jedná o soukromá práva, přidržuje se osnova jejich tradičního rozdělení na práva osobní a na práva majetková. Tomu odpovídá i návrh vnitřního členění zákoníku. Osobním právům se věnují především prvá a druhá část zákoníku, majetkovým především části třetí a čtvrtá. Pátá část, která shrnuje ustanovení společná, přechodná a závěrečná, má především technickou povahu. Osu celé úpravy představuje člověk a jeho zájmy. Právní postavení člověka jako jednotlivce, včetně úpravy práv výlučně a přirozeně spjatých s jeho osobou, je klíčové téma první části zákoníku. Otázky spojené s jeho rodinou a rodinnými vztahy upravuje druhá část; jeho majetku a osudu tohoto majetku po smrti člověka se věnuje třetí část. Čtvrtá část upravuje obligační právo, tedy práva a povinnosti vzniklé člověku vůči jiným z jeho soukromého styku s jinými osobami. Antropocentrické pojetí občanského zákoníku však nepomíjí téma právnických osob jako dalšího subjektu soukromých práv a povinností. Z toho důvodu také zejména obecná část věnuje úpravě postavení právnických osob značnou pozornost s tím, že tato úprava má platit subsidiárně pro všechny právnické osoby podle českého právního řádu, nebot' v občanském, nikoli v obchodním zákoníku nebo jiném zákoně, má být ze systémového hlediska těžiště úpravy statusových otázek právnických osob. Vychází se ale z pojetí, že právnické osoby vytvářejí

131 Důvodová zpráva k zákonu č. 89/2012 Sb., občanský zákoník, s. 12-13.

132 Tamtéž, s. 20. 
lidé proto, aby sloužily jejich zájmům. Nefinguje se tudíž rovnost obou skupin subjektů, nebot' ta fakticky není a v řadě případů není ani možná. Zjevný rozdíl je v konstrukci osobních práv, dále se jedná o rozsáhlou oblast práva rodinného a dědického, nehledě k tomu, že ani při určitých typech smluv nemohou právnické osoby jako určitá smluvní strana vůbec vystupovat (při nájmu obydlí, při výměnku, smlouvě o důchodu apod.)."133

Autoři občanského zákoníku se tak jednoznačně přiklonili k té části právních teoretiků (např. k Fritzi Rittnerovi nebo Viktoru Knappovi), kteří zastávají tezi o nerovnosti fyzických a právnických osob. Fyzická osoba jako schematický právní model člověka (biosociální bytosti) je podle nich primární. Druhou skupinu tvoří právnické osoby, na které je nutné hledět jako na pomocnou právní konstrukci, a to i přesto, že jsou zřetelné tendence svěřit jim maximum právní výbavy, která dřive náležela výhradně osobám fyzickým. Jak je uvedeno v komentáři Petra Lavického, právnické osoby nejsou vlastním konečným cílem, ale specifickou právní formou, prostřednictvím které lidé nebo skupiny lidí realizují své ekonomické nebo jiné cíle. ${ }^{134}$

V současné právní doktríně však nejsou ojedinělé názory, které se vrací k myšlenkám brněnských normativistů a Hanse Kelsena. Vázanost pojmu osoba na člověka není podle těchto právních teoretiků správný přístup, protože člověk existuje v reálném světě, kdežto pojem osoba existuje pouze v právním řádu. Při analýze pojmu osoba, tedy ryze právního pojmu, nemůžeme zároveň poznávat člověka, který existuje v reálném světě. Podle $\S 17$ ObčZ ,práva může mít a vykonávat jen osoba. Povinnost lze uložit jen osobě a jen vůči ní lze plnění povinnosti vymáhat.“ Z této formulace vyplývá, že osoba je jakýsi bod, ke kterému jsou přičítána práva a povinnosti. Tento bod existuje pouze v právu, a kdyby k němu právní rád nepřičítal práva a povinnosti, vůbec by neexistoval. Pokud právní řád k určitému bodu přičítá konkrétní práva a povinnosti, pak tento bod existuje pouze společně s těmito právy a povinnostmi, které jsou k němu přičítány.

Z toho vyplývá, že přičitatelnost je shodná s právní osobností, být osobou totiž znamená mít soubor práv a povinností. Tím se dostáváme k premise normativní právní teorie, podle které je osoba personifikovaným souborem právních norem. Toto strohé statické vymezení osoby je však nedostatečné z toho důvodu, že nepostihuje dynamiku společenských vztahů. Pojem osoba totiž není samoúčelný, ale musí zároveň umožňovat vznik, změnu a zánik práv a povinností. Tato dynamika ale nevyplývá z teoretické možnosti mít tato práva a povinnosti, ale vyplývá z toho, že osoba má rozum a vůli s těmito právy a povinnostmi nakládat. Každému bodu přičitatelnosti je tedy potřeba přičítat rovněž rozum a vůli. Tím se oklikou vracíme k tezi, že osoba je s člověkem prímo (v př́padě osob fyzických) nebo neprrímo (v případě osob právnických, které jednají prostřednictvím osob fyzických) spjata. Rozhodně však z této teze nemůžeme vyvodit skutečnost, že si jsou fyzické a právnické osoby nerovné. Sílu tohoto pojetí spatřuji v tom, jak se jednoduše a elegantně vypořádává s nekončícími disputacemi o vzájemném teoretickém vymezení obou typů osob, byt' jde o myšlenky téměř sto let staré.

Bez ohledu na podstatné rozdílnosti mezi jednotlivými př́stupy k vymezení fyzických a právnických osob je nicméně možné konstatovat, že poslední dvě století prochází koncept obou těchto typů osob v právním smyslu kontinuálním procesem sbližování, který po

\footnotetext{
133 Tamtéž, s. 21-22.

134 LAVICKÝ, Občanský zákoník I. Obecná část (\$ 1-654). Komentár̆, s. 136.
} 
formální stránce směřuje ke sjednocení právní výbavy (právního statusu) osoby fyzické i právnické. V tomto smyslu je nutné právo osob v aktuálně platném občanském zákoníku (navzdory důvodové zprávě) vykládat. Současná česká právní doktrína plně reflektuje dosavadní vývoj této problematiky v kontinentální právní kultuře a „lze tedy obecně konstatovat, že osoba v právním smyslu představuje modelovou, právní charakteristiku společnou pro soubor lidských bytostí (tímto modelem je osoba fyzická) a k nim se řadící soubor různých útvarů, jimž právo přiznává postavení (právní status), který je v nejobecnějším pohledu společný pro všechny osoby v právním smyslu a který umožňuje jejich začlenění do souboru právních vztahů v postavení jejich subjektů. Osoba v právním smyslu je tedy nositelem právního statusu, který z ní činí způsobilý subjekt právních vztahů, tedy nositele subjektivních práv a subjektivních povinností z těchto vztahů vyplývajících."135

\section{Závěr}

Jedním z cílů této studie bylo přinést historizující pohled na pojem osoba v právním smyslu. Dnešní význam pojmu „osoba“ a jeho odlišení od pojmu „,̌̌lověk“ je totiž výsledkem dlouhého a komplikovaného historického vývoje. Právo až v relativně pozdní fázi přebíralo výsledky tohoto vývoje, který probíhal v jiných společenských oborech. Bez tohoto vývoje by právní doktrína nedospěla $\mathrm{k}$ dnešnímu pojetí osoby.

Význam pojmu osoba (řecky prosopon, latinsky persona) v antickém Řecku a ̌ímě dodnes nebyl zcela objasněn ve všech svých nuancích. Je však zřejmé, že jej nemůžeme ztotožňovat s dnešním pojmem osoba v právním smyslu. Pojem persona byl mnohoznačný a pravděpodobně neměl žádný právně-technický význam. V antice sice došlo k formování pojmu osoba ve smyslu lidského individua vybaveného rozumem, nicméně nelze přeceňovat význam tohoto vývoje pro dnešní konstrukt osoby v právním smyslu.

Další impuls k vývoji vnímání pojmu osoba přišel až v období raného a vrcholného středověku, kdy se tehdejší teologové a filozofové zabývali zejména trojjediností Boha jako jediné božské substance (tres personae, una substantia). Přestože podle některých právních historiků křest’anští myslitelé definovali všechny obecně přijímané znaky osoby v právním smyslu, přikláním se k názoru, že v tomto období nedošlo k abstraktnímu vymezení pojmu osoba v dnešním smyslu.

O významný posun ve vnímání osob v právním smyslu se zasloužili novověcí myslitelé Samuel von Pufendorf, Christian Wolff a Daniel Nettelbladt, kteří rozpracovali koncept tzv. morální osoby. Všem třem uvedeným myslitelům je vlastní statusové pojetí osoby, to znamená, že veškerá práva osoby jsou projevem toho či onoho statusu. Díky statusu se člověk stává osobou v právním slova smyslu a náleží mu osobnostní a majetková práva. Při změně statusu člověk některá práva získal, jiná zase ztratil. Statusová nauka je pozůstatkem feudálního práva - právní subjektivita se odvozovala od př́ílušnosti ke stavu (šlechta, duchovenstvo, měšt’ané), kdy příslušníci jednotlivých stavů disponovali rozdílnými právy a povinnostmi.

Zásadní zlom přináší racionalismus vrcholného novověku, kdy pojem osoba dostal nový význam, který je založen na chápání osoby jako obrazu lidské bytosti. Pojem osoba je vnímán jako výraz pro označení člověka ve smyslu sebeuvědomělého subjektu, který je odpovědný za své činy. Přispěl k tomu mimo jiné René Descartes, podle kterého se jako

135 LAVICKÝ, Občanský zákoník I. Obecná cást (§ 1-654). Komentář, s. 136. 
subjekt (osoba) kvalifikuje ten, kdo myslí. Immanuel Kant se zase zabýval důstojností člověka, kdy tvrdil, že každý člověk, jakožto účel sám o sobě, má svou vnitřní hodnotu, tj. důstojnost. Důstojnost vysvětluje jako lidskost, která je integrální součástí každé osoby. Každý člověk má zároveň přirozené právo na uznání své osobnosti, které je založené v ní samotné. Tím Immanuel Kant definitivně překonal koncept, podle kterého se právní osobnost člověka odvozuje od jeho sociálního statusu.

Georg Wilhelm Friedrich Hegel obohatil pojem osoba o atribut společenského vztahu. Hegel tak překonal Kantův individualismus, protože podle něj autonomie jednajících subjektů nemůže mít apriorní povahu. Individualizace je proces probíhající současně se socializací. Osoba není pro Hegela žádný ideální apriorní model, nýbrž představuje výsledek procesu probíhajícího v rámci souboru společenských vztahů, jichž se osoba účastní. Pro Hegela je při definování osoby významný, podobně jako pro Reného Descarta, rozum jedince, resp. jeho sebeuvědomění.

Na myšlenky Immanuela Kanta navázal významný německý právník Friedrich Carl von Savigny. Ten přichází se zdařilou definicí subjektivity, kdy říká, že každý člověk je osobou ve smyslu subjektu práva a je tedy právně způsobilý. Friedrich Carl von Savigny také připouští, že se uměle vytvořené entity (tedy právnické osoby) mohou stát nositeli subjektivních práv a povinností. Subjektivita se tak konečně stala pouze právním pojmem použitelným jak pro fyzické osoby, tak pro osoby právnické. Friedrich Carl von Savigny je prvním právníkem, který chápal pojem osoba v právním smyslu podobně jako dnešní právní doktrína.

K završení racionalistického pojetí osob v právním smyslu došlo na pozadí vývoje vnímání pojmu právnická osoba, který probíhal ve 2. polovině 19. století. Především Savignyho dílo nazvané Systém dnešního řimského práva zásadně ovlivnilo i výklad rakouského zákoníku, byt' se pochopitelně Savignyho myšlenky nemohly projevit v samotném textu kodexu. Díky Savignyho myšlenkám nebyla osoba ztotožňována pouze s člověkem, ale byla vnímána čistě jako nositelka subjektivních práv. V tomto období dochází k odmítnutí posledních reziduí statusové nauky. Osobu je konečně možné vnímat jako zájmovou jednotku uznanou právním řádem, který jí propůjčuje právní subjektivitu.

Co se týče moderních teorií osob v právním smyslu, můžeme zřetelně pozorovat střet dvou přístupů. První, tradiční proud, reprezentovaný zejména Rolfem Ostheimem či Fritzem Rittnerem, se vrací ke kořenům práva jako takového a akcentuje přirozenoprávní a racionalistický původ pojmu osoba. Rolf Ostheim definuje právní rád jako donucovací systém. Předmětem státního donucení může být pouze lidské jednání, které jakožto volní jednání směřje k dosažení určitých cílů. Motivem pro dosažení cílů je uspokojování zájmů a potřeb člověka. Právo je tedy řád, který se vztahuje ke sledování lidských zájmů a který je vybaven donucovací mocí. Podle Rolfa Ostheima zájem a vůle tvoří jediný správný bod přičitatelnosti, k němuž se vztahuje právní osobnost. V momentě, kdy stát hledí na zájmy všech podřízených osob stejně, nahlížíme na tyto osoby jako na subjekty práva.

Druhý př́istup nahlíží na pojem osoby z pozic postmodernismu. Postmodernisté odmítají historický vývoj tohoto pojmu od antiky po moderní dobu a vytváŕí zcela nové paradigma. Osoba z pohledu postmodernismu nezahrnuje pouze člověka, ale jakoukoliv entitu, o které právo rozhodne, že je z pohledu práva subjekt. O přiznání právní subjektivity rozhoduje zákonodárce a toto rozhodnutí není politicky neutrální. Z toho vyplývá, že určení, co je a co naopak není právním subjektem, je politický problém. Tím je popřeno histo- 
rickým vývojem vybudované pojetí fyzické osoby jakožto primárního právního subjektu odvozeného od člověka, tedy od myslící rozumové nezávislé substance.

Přestože nelze význam postmodernismu přeceňovat, tak svým akcentem na pragmatičnost lidského chování vede k rozvolňování vazby pojmu osoba na atributy odvozené od člověka a otvírá prostor pro formulaci tohoto pojmu ryze účelově, což v konečném důsledku vede ke sbližování právního modelu fyzické a právnické osoby (resp. jejich právní výbavy), které ostatně probíhá posledních 200 let. Fyzické osoby však i nadále zůstávají jakousi privilegovanou kategorií - mají aktivní a pasivní volební právo, mohou se stát členy politických stran nebo církví, jsou subjektem základních lidských práv, například práva na život, na soukromí, svobody slova, práva na vzdělání atp. To vše si lze u právnických osob těžko představit.

Na základě analýzy historického vývoje můžeme konstatovat, že při definování osob vycházely právní rády západních demokratických států v 20. století z osvícenských a přirozenoprávních principů formulovaných zhruba od poloviny století osmnáctého. Obraz člověka v právním řádu je obrazem jedinečného, na sebe odkázaného individua, které sice také žije v sociálních a dalších společenských vztazích, jako takové je ale vůči těmto vztahům primární. Základní jednotkou právního řádu je podle přirozeného práva jedinečné, svobodné, na sebe odkázané individuum, tj. právní subjekt.

Do dnešního právního řádu nevstupuje člověk se svým metafyzickým a transcendentálním určením. Vstupuje do něj jako individuum obdařené svobodou volit si své určení samo. To se projevuje např́iklad v obsahu základních občanských a lidských práv a svobod - ve svobodě náboženského vyznání, svobodě pohybu, svobodě projevu, v právu vlastnit majetek apod. Nejde o metafyzickou svobodu, ale o subjektivní svobodu jednotlivce ve smyslu svobodné volby a svobodného sebeurčení. Stát přitom nevystupuje jako entita, která by naplňování obsahu individuálních práv a svobod vynucovala. Stát vystupuje v roli garanta zajišt'ujícího právě svobodu volby každého právního subjektu.

Nyní se dostáváme $\mathrm{k}$ dalšímu cíli této studie, tj. porovnání právní úpravy fyzických osob v obecném zákoníku občanském z roku 1811 (ABGB) a českém občanském zákoníku z roku 2012, a to zejména úpravy tzv. pasivního statusu osoby v právním smyslu (tj. právní osobnosti). Pojetí osoby v ABGB můžeme vnímat jako výsledek racionalistického právního myšlení, resp. přirozenoprávní teorie. Redaktoři rakouského obecného zákoníku občanského (zejména Franz von Zeiller) vycházeli z Kantova pojetí lidské důstojnosti. Každý člověk má přirozené právo na uznání své osobnosti, které je založené v ní samotné. Tím bylo konečně překonáno statusové pojetí právní osobnosti. Zákoník na každého jednotlivce nazíral jako na subjekt soukromoprávních vztahů a odsouval dřívější hledisko vycházející z postavení (statusu) konkrétního subjektu. Proto § 16 ABGB deklaroval, že má každý člověk vrozená, samotným rozumem poznatelná práva. Zákoník tím zdůrazňuje, že vrozená práva nejsou lidem propůjčována státem, ale náleží každému člověku z titulu jeho lidské důstojnosti. $Z$ tohoto konstruktu vyplývá idea rovnosti všech lidí. ABGB je tak zákoníkem, který již na počátku 19. století ustanovil občanskou rovnost před zákonem a zcela otevřeně ji proklamoval. Zákoníkem zdůrazněný základní princip rovnosti je nesmírně cenný a je to jeden z faktorů, který kodexu umožnil přežít do dnešních dnů. Ustanovení § 16 ABGB také vyjadřuje zásadu dovolenosti jednání, která nebyla do přijetí zákoníku nikde upravena. Z § 16 se dovozovala i další základní lidská práva, což bylo obzvláště důležité př́i absenci podobných ustanovení na ústavní úrovni. 
Na druhou stranu ale nelze význam $\S 16 \mathrm{v}$ době přijetí zákoníku přeceňovat. $\S 18$ ABGB totiž stanovil, že „každý je způsobilý nabývati práv za podmínek, ustanovených zákony“ a právě na základě tohoto ustanovení bylo možné způsob nabývání práv diferencovat podle různých kritérií. Roli hrálo např. pohlaví, věk, náboženské vyznání nebo právě příslušnost $\mathrm{k}$ určitému stavu. Přestože tedy obecný zákoník občanský formálně zakotvil rovnost všech lidí, určitá práva mohly na základě zvláštních předpisů nabývat pouze některé skupiny obyvatel. Tyto disproporce v pojetí osoby v právním smyslu byly odstraněny až pozdějším doktrinálním a judikatorním vývojem.

Pojetí osob v právním smyslu bylo později v rakouské doktríně poznamenáno střetem Kantovy a Hegelovy filozofie. Zatímco redaktoři rakouského zákoníku vycházeli z Kantových myšlenek, rakouská právní doktrína v druhé polovině 19. století vnímala osobu spíše z pohledu Hegela. Další konflikt probíhal mezi stoupenci přirozenoprávního a právně pozitivistického pohledu na pojetí osoby v právním smyslu.

V prvorepublikové doktríně sice přetrvalo přirozenoprávní nahlížení na člověka, to ale bylo do jisté míry ovlivněno brněnským normativismem, ke kterému se přiklonili také autoři jediného českého komentáře k ABGB. Jaromír Sedláček problematiku osoby vnímal jako personifikaci právní normy, přičemž každý normotvorný orgán se považuje za osobu. V normě je stanovena povinnost a tento subjekt povinnosti nazývá osobou. Podle Františka Weyra je při zkoumání právní osobnosti klíčové to, že je příslušný subjekt schopen být nositelem práv a povinností. A jako představitel brněnského normativismu podobně jako Sedláček přidává další schopnost osob v právním smyslu, a to schopnost normotvornou. I v soukromoprávní oblasti totiž dochází k normotvorbě, byt' sekundární v podobě uzavírání smluv, která předpokládá souhlas všech smluvních stran.

V podobném duchu pracoval s pojmem osoba v právním smyslu rakouský právní teoretik Hans Kelsen, podle kterého je pojem osoby možné chápat pouze jako umělou myšlenkovou pomůcku, pomocný pojem, který si právo vytvořilo za účelem názornějšího podání své látky pod vlivem antropomorfizující a personifikující právní mluvy. Osoba je podle něj pouze personifikující souhrnný název pro souhrn práv a povinností. Fyzické a právnické osoby přitom chápe stejně. Fyzickou osobou podle něj není člověk, fyzickou osobu vnímá jako personifikaci norem upravujících chování člověka. Právnická osoba je naproti tomu personifikace norem upravujících chování určité množiny lidí. Kelsen uzavírá, že osoba je pouhou personifikací určitého komplexu norem a tím personifikací určitého dílu objektivního právního řádu, který tvoří mezi všemi jím založenými právy a povinnostmi organickou jednotu. Právu jedné osoby vždy odpovídá povinnost druhé osoby.

Pro normativisty byl při vymezení pojmu osoba také významný pojem ,„přičitatelnosti“. Osoba je totiž podle nich entita, které přičítáme práva a povinnosti. Pojem přičitatelnosti má pro pochopení pojmu osoby centrální význam. Být osobou tak podle platného práva musí znamenat být ,čímsi““, čemu přičítáme práva a povinnosti. Pro pochopení toho, co máme rozumět pod pojmem osoby, nemá z normativního hlediska smysl a priori vycházet z pojmu osoby, nýbrž z toho, co způsobuje, že „něco“ můžeme za osobu považovat. Příčetnost přitom musí být stanovena normou.

Co se týče občanského zákoníku z roku 2012, jeho redaktoři označili za ideový zdroj rekodifikace rakouský obecný zákoník občanský, což se samozřejmě projevilo i na úpravě osob v právním smyslu. Pojetí osob v aktuálně platném občanském zákoníku je tak př́mým dědicem Zeillerova přirozenoprávního myšlení, které bylo inspirováno Kantovým 
pojetím lidské důstojnosti. Nejvíce zřetelné je to zejména v př́ípadě $§ 19$ ObčZ, který de facto recipuje $\S 16$ ABGB. Toto ustanovení rakouského zákoníku mělo klíčový význam pro soudní aplikaci práva zejména v době, kdy nebyla na ústavní úrovni zakotvena základní lidská práva. Dnes jsou základní právní principy a lidská práva upraveny ústavními předpisy a mezinárodními smlouvami, význam těchto dvou ustanovení je tak nyní spíše deklaratorní.

Inspirace $\S 16$ ABGB je významná i pro vymezení vztahu mezi pojmy člověk a osoba. Optikou autorů aktuálně platného občanského zákoníku je nutné sled př́íčin a účinků v oblasti pojetí člověka jako osoby vykládat takto: východiskem je existence člověka, který je ze své existence vybaven vrozenými přirozenými právy, což vede k důsledku, že je považován za osobu. Tento proces se děje mimo zákon, který stanoví jen meze uplatňování přirozených práv a způsob jejich ochrany. Člověk je reálným biosociálním základem jeho odrazu v právu (tedy fyzické osoby) a fyzická osoba je souborem předpokládaných, nicméně v realitě existujících či očekávaných vlastností člověka, nezbytných pro vstup člověka do právních vztahů.

Na tomto závěru nic nemění ani poněkud nešt’astná formulace $§ 19$ ObčZ, podle kterého se člověk ,považuje za osobu“. Přestože by se mohlo zdát, že zákonodárce zde zakotvuje fyzickou osobu jako fikci člověka, není tomu tak. Tento výklad by zcela popřel několik století dlouhý vývoj právní teorie vymezující obsah pojmu osoba v právním smyslu. Podobně nešt'astně občanský zákoník na desítkách míst používá termín člověk namísto pojmu fyzická osoba. Tento postup není metodologický správný a odporuje doktrínou vymezenému pojmu osoba. Rakouský občanský zákoník je v tomto ohledu přesnější a o člověku hovoří pouze na třech místech (včetně § 16, který zdůrazňuje přirozenoprávní východiska zákoníku), všude jinde je použit pojem osoba v různých modifikacích. Redaktoři ABGB správně vnímali konstrukt fyzické osoby jako zjednodušený model člověka, který je použitelný v právních vztazích. Je otázkou, jestli si autoři občanského zákoníku z roku 2012 byli vědomi těchto teoretických východisek, každopádně do samotného textu kodexu se nepromítla.

Můžeme tedy potvrdit hypotézu vyřčenou v úvodu této studie: Redaktoři občanského zákoníku z roku 2012 se nezaměřili na precizní teoretické vymezení osob v právním smyslu, resp. na odlišení pojmu osoba od pojmu člověk, a nerespektovali tak několik staletí trvající vývoj právní doktríny v této oblasti. Naproti tomu pojem osoby byl v ABGB vymezen přesněji a v souladu s tehdejšími poznatky právní vědy.

Tuto studii je však přesto možné uzavřít konstatováním, že pojem fyzické osoby je v obou zákonících nutné chápat jako redukci multidimenzionální povahy člověka, kdy právo člověka akceptuje, resp. jej proměňuje do podoby, ve které může člověk pomocí právních institutů prosazovat své partikulární zájmy (at' již osobní nebo ekonomické). Jde o transformaci reálné podstaty člověka v abstraktní pojem, ve srovnání s reálným člověkem značně zjednodušený na několik elementárních znaků, se kterým je právo schopno dále nakládat. 